\title{
The Huehuetla quarry, a Turonian deposit of marine vertebrates in the Sierra Norte of Puebla, central Mexico
}

\author{
Jesús Alvarado-Ortega, Kleyton Magno Cantalice Severiano, \\ Jair Israel Barrientos-Lara, Jesús Alberto Díaz-Cruz, \\ and Bruno Andrés Than-Marchese
}

\begin{abstract}
The Huehuetla quarry is a new fossiliferous site located near the town of the same name, into the region of Sierra Norte, northern Puebla, Mexico. This work represents the formal beginning of paleontological research on this site. This quarry occupies an area of about one hectare that is scarcely exploited with commercial purposes. The rocks rarely extracted in this site are slabs of nice jet-black carbonated shales with microscopic crystals of pyrite; which also are resistant, oily and stinky. The fossils recovered in these slabs belong to different marine vertebrate taxa, which include complete and articulated specimens as well as isolated bones. When it is preserved, the calcium phosphate of these bones is softened and filled with large calcite and pyrite crystals. Taxa represented in Huehuetla quarry constitute a peculiar assemblage that includes Nursallia aff. tethysensis, Tselfatia formosa, Goulmimichthys roberti, Hastichthys, indeterminate species of Enchodus and Clupeidae, as well as an indeterminate mosasaur. This is the first report of the pycnodontid $N$. tethysensis and of the dercetid Hastichthys fish all over America. This work provides evidence supporting the taxonomical validity of the species $G$. roberti. Based on its fossil content and lithology, it is determined that the fossil bearing strata of the Huehuetla quarry are part of the Turonian marine deposits of the Agua Nueva Formation.
\end{abstract}

Jesús Alvarado-Ortega. Instituto de Geología, Universidad Nacional Autónoma de México, Circuito de la Investigación S/N, Ciudad Universitaria, Delegación Coyoacán, Ciudad de México 04510, México. alvarado@geologia.unam.mx

Kleyton Magno Cantalice Severiano. Instituto de Geología, Universidad Nacional Autónoma de México, Circuito de la Investigación S/N, Ciudad Universitaria, Delegación Coyoacán, Ciudad de México 04510, México.kleytonbio@yahoo.com.br

Jair Israel Barrientos-Lara. Posgrado en Ciencias Biológicas, Universidad Nacional Autónoma de México, Circuito de la Investigación S/N, Ciudad Universitaria, Delegación Coyoacán, Ciudad de México 04510, México. j4ir@me.com

Alvarado-Ortega, Jesús, Cantalice Severiano, Kleyton Magno, Barrientos-Lara, Jair Israel, Díaz-Cruz, Jesús Alberto, and ThanMarchese, Bruno Andrés. 2019. The Huehuetla quarry, a Turonian deposit of marine vertebrates in the Sierra Norte of Puebla, central Mexico. Palaeontologia Electronica 22.1.13A 1-20. https://doi.org/10.26879/921

palaeo-electronica.org/content/2019/2450-huehuetla-turonian-vertebrates 
Jesús Alberto Díaz-Cruz. Posgrado en Ciencias Biológicas, Universidad Nacional Autónoma de México, Circuito de la Investigación S/N, Ciudad Universitaria, Delegación Coyoacán, Ciudad de México 04510, México. vertebrata.j@gmail.com

Bruno Andrés Than-Marchese. Museo de Paleontología "Eliseo Palacios Aguilera", Secretaría de Medio Ambiente e Historia Natural, Calzada de Los Hombres llustres s/n., Tuxtla Gutiérrez, Chiapas, México. bruthmar@gmail.com

Keywords: Huehuetla; Turonian; Puebla; Agua Nueva Formation; fishes; Mosasauria

Submission: 30 August 2018. Acceptance: 20 February 2019.

\section{INTRODUCTION}

In 2013, Mr. Félix Aranguthy and his father, Ranulfo Aranguthy Contreras, quarry workers and sellers of ornamental rocks in Tepexi de Rodríguez, Puebla, central Mexico, recovered some fossils in the jet-black flagstones of carbonated shales from a site located in the Sierra Norte de Puebla region, near the Huehuetla town (Figure 1). Since 1981, Mr. Ranulfo Aranguthy participates as field assistant in paleontological research projects of the Instituto de Geología of the Universidad Nacional Autónoma de México (UNAM). Mr. Félix and his father gave these fossils to the first author of this work.

Since the first glance, these fossils were identified as a significant Late Cretaceous assemblage, preserved into a distinctive lithology, from a region with no previous record of fossil fishes. Thus, Huehuetla joins a series of Mexican Late Cretaceous paleontological sites distributed from north to south occupying a region with high biogeographical interest, which north of the country include the Vallecillo quarry in Nuevo León (Blanco et al., 2001), as well as the La Mula, Los Temporales, Venustiano Carranza, and El Rosario quarries in Coahuila; in the south of the country account with the El Espinal and El Chango quarries in Chiapas and the Arroyo Las Bocas, Taxco el Viejo, Temalac, Zoquiapa, Tecalpulco, and Tepetlapa in Guerrero, (AlvaradoOrtega et al., 2006a, 2006b, 2009); and in the center of the country have the Muhi quarry in Hidalgo (González-Rodríguez et al., 2016), the Xilitla quarry in the state of San Luis Potosí (MaldonadoKoerdell, 1956); as well as the San José de Gracia quarry in the southern region of Puebla, recently reported by Alvarado-Ortega et al. (in press). In this huge Mexican region three marine domains converge within the ancient Gulf of Mexico, the western or Caribbean end of the Tethys Sea, the southern mouth of the Cretaceous North American Interior Seaway, and the western North American edge of the Paleopacific Ocean. This geographical situation could exercise significant control over the North American Late Cretaceous marine faunal composition. The addition of any new localities in this region will complement the understanding of the biogeographic patterns of the Late Cretaceous marine faunas in the southern extreme of North America. Therefore, the aim of this work, which starts the formal study of Huehuetla, is to report the discovery of this fossiliferous site and to describe its general paleontological and geological features.

\section{Geological Setting}

The Huehuetla quarry is an area of about one hectare, once occupied by a small coffee plantation, where the soil is now completely removed. Today, the local people rarely extract slabs in this site that are used to cover floors or walls. The Huehuetla quarry is located between the coordinates $20^{\circ} 7^{\prime} 45.9^{\prime \prime} \mathrm{N}$ and $97^{\circ} 37^{\prime} 48.3^{\prime \prime} \mathrm{W}, 100 \mathrm{~m}$ at the west of the road between the Huehuetla town and the Dimas López village, and $3 \mathrm{~km}$ north from the Huehuetla downtown. The excavation in this quarry is extremely shallow, less than $1 \mathrm{~m}$; however, this can be recognized as an outcrop of the Agua Nueva Formation that was deposited within the JurassicTertiary Tampico-Misantla Basin (Gray et al., 2001).

The strata exploited in Huehuetla consist of finely laminated jet-black carbonated shales, oily, bituminous, and with a rotten smell, which are intercalated with scarce millimetric horizons of black flint and some thin layers of bentonite. When they are weathering, the color of these rocks is gradually clarified to become gray. Microscopic crystals of pyrite are randomly scattered within these hard-carbonated rocks as well as over and filling the empty spaces of the fossil bones. Given the dense vegetation in the region, it has not been possible to recognize the extension of the fossiliferous strata in Huehuetla, nor their upper and lower contacts. Up to now, the fossil assemblage recovered in this quarry includes marine fishes and rep- 


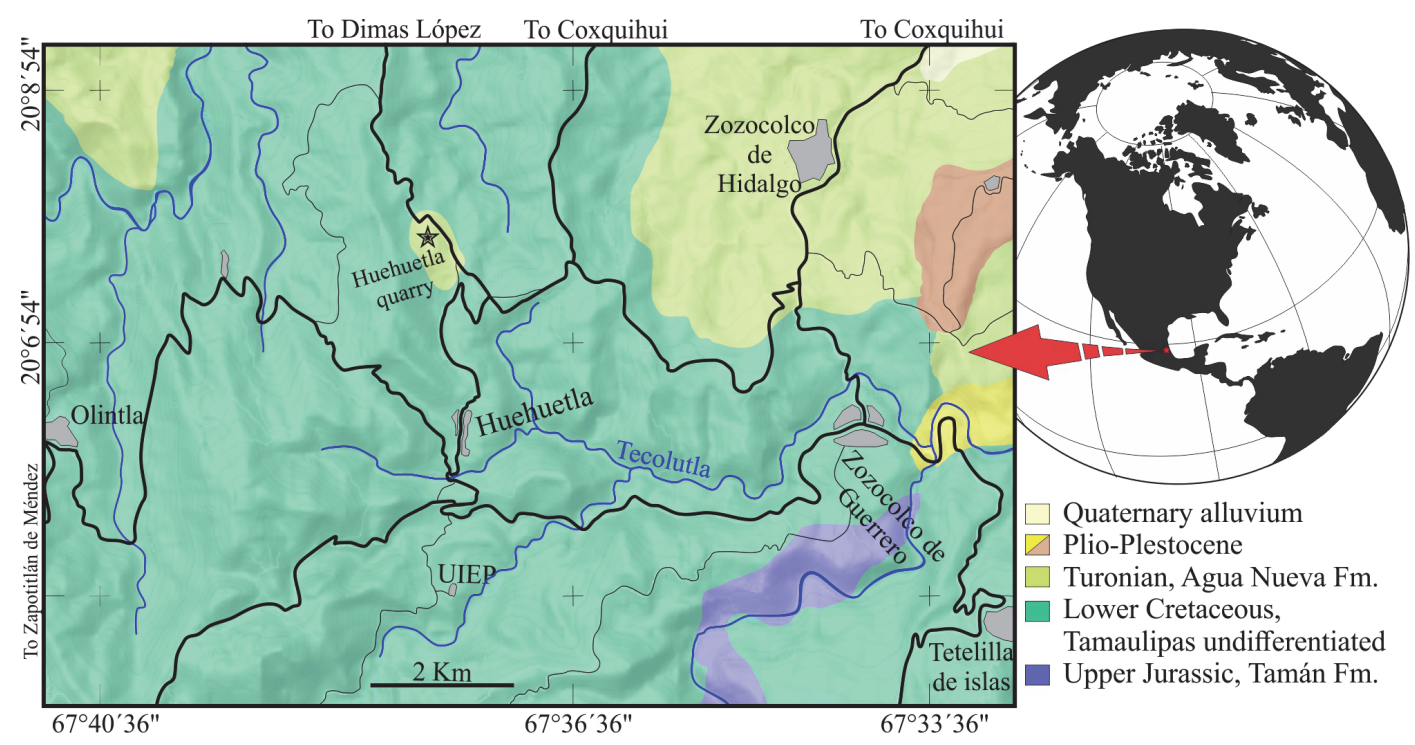

FIGURE 1. Geological map of the Huehuetla quarry, Puebla, Mexico. In this work this map includes the surrounding area of this quarry as a Turonian outcrop deposit belonging to the Agua Nueva Formation (modified from Servicio Geológico Mexicano, 2004).

tiles, as well as large coprolites and scarce small bivalves.

The Servicio Geológico Mexicano (2004) indicates that the area occupied for the Huehuetla quarry sets on undifferentiated outcrops of the "Tamaulipas" geological unit, near to outcrops of the Tamán, San Felipe, and Agua Nueva formations. There are reasonable lithological and paleontological evidences to point out that the rocks of the Huehuetla quarry belong to the Agua Nueva Formation (Figure 1).

The Tamán Formation is a Late Jurassic (Late Kimmeridgian-Tithonian) sequence of dark gray shales and microcrystalline black limestones named by Heim (1940) and exposed in San Luis Potosí and surrounding states. Strata of this formation are exposed about $6 \mathrm{~km}$ to the southeast far from Huehuetla. So far, no fossil vertebrates have been collected in this formation except for a primitive teleosts recovered near the Tamán town, San Luis Potosí, already described as Leptolepis tamanensis Dunkle and Maldonado-Koerdell, 1953.

The "Caliza Tamaulipas", named by Stephenson (1922), represents a sequence of crystalline white-gray-yellowish limestones with few nodules and bands of white to black flints. Muir (1936) divided this sequence in three units: the Tamaulipas Inferior Formation of Neocomian to Lower Aptian age, the Otates Horizon of Middle-Upper Aptian age, and the Tamaulipas Superior Formation of Albian-Cenomanian age. So far, the fossils recovered in this stratigraphical sequence include invertebrates and microfossil but not vertebrates.

Stephenson (1922) also identified the strata exposed in the state of Nuevo León, which include black carbonated shales and black laminated limestones with fine flint horizons and abundant specimens of Inoceramus (Mitylodoes) labiatus (Schlotheim, 1813) intercalated with fine layers of bentonite. Today these strata are known as part of the Agua Nueva Formation. Fossils recovered in this formation include numerous microfossils and macroscopic invertebrate taxa, as well as fishes and marine reptiles that support the Late Cenomanian-Turonian age of this formation (CarrilloBravo, 1971; Ice and McNulty, 1980; Blanco-Piñón, 2003; Giersch, 2014; among others).

The San Felipe Formation is a sequence of limestones, toubaceous horizons, and gray marls that include scarce flint and pyrite nodules (LópezRamos, 1983; Santiago-Carrasco et al., 2000). The fossils already recovered from this formation include numerous microfossils and invertebrates but not vertebrates. Pessagno (1969) claimed that the age of this formation extends from the Late Cenomanian to Early Santonian; however, authors suggest that it is between the Coniacian to Campanian (Sohl et al., 1991; among others).

As it is exposed in previous paragraphs, the lithological characteristics and the paleontological assemblage of the Huehuetla quarry do not match with those of the Tamaulipas Inferior and the San Felipe formations or the Otates Horizon. In con- 
trast, these match with those of the Agua Nueva Formation, which bears well-preserved fossil vertebrates.

\section{MATERIAL AND METHODS}

Preparation methods. Fossils were mechanically prepared with needles and odontological devices under stereoscopic microscope. When necessary, the fossils were glued with cyanoacrylate; they were hardened with a weak solution of plexigum diluted in methacrylate acetate applied with a fine brush. As noted in the figures of this work, the specimens studied were photographed under white light and after being coated with ammonium citrate. Anatomical nomenclature and abbreviations. The taxonomical identification of fossil taxa described here, as well as the anatomical nomenclature and abbreviations used, are based on the publications cited in the main text.

Institutional abbreviations. Fossils from the Huehuetla quarry are deposited and catalogued under the acronym IGM that correspond to the Colección Nacional de Paleontología, housed into the Museo María del Carmen Perrilliat at the Instituto de Geología, UNAM. This site is recorded in the catalog of paleontological sites of this collection as IGM-loc 3889 and JAO 299 as field number.

\section{SYSTEMATIC PALEONTOLOGY}

Order PYCNODONTIFORMES Berg, 1937

Family PYCNODONTIDAE Agassiz, 1833 sensu

Nursall, 1996

Genus NURSALLIA Blot, 1987

Nursallia tethysensis Capasso, Abi Saad, and

Taverne, 2009

Nursallia aff. tethysensis

Referred material. IGM 6618, incomplete and partial covered specimen in right side and without the head, reaching 165 and $96 \mathrm{~mm}$ of length and height, respectively (Figure 2).

Description. The neural and hemal arches and spines are almost entirely preserved as impressions. These wide structures contact with neighbor elements showing complex interdigitated sutures surrounding the notochord. The basal halves of neural and hemal spines have well-developed anterior sagittal flanges. The ribs are stout and show anterior and posterior expanded wings.

The dorsal fin is incompletely preserved; however, the shape of both anal and dorsal fins seems to be falcate (e.g., Poyato-Ariza and Wenz, 2002, figure 34). The little elevated posterior part of the dorsal fin consists of at least 36 short rays, which are supported on the same number of short pterygiophores. The anal fin consists of about 55 rays supported for 54 pterygiophores, including about 8 or 10 rays and pterygiophores almost entirely covered in its middle part of the fin. The anterior eight anal rays are the longest and form the acuminated portion in this fin. The caudal fin is homocercal, high, short, and has a continuous and rounded posterior middle edge. There is well-defined caudal peduncle. This fin consists of about 40 principal caudal rays. Although the tip of the ventral caudal fin lobe is lost; the ventral and dorsal caudal fin lobes are projected vertically and seem to share the same triangular shape, three times higher than long.

The squamation in this fish resembles the peltate type described by Nursall (1996, figure 19). In this specimen, the anterior region of the trunk is covered for an indefinite number of scale rows. Although the scales on the middle ventral region of the abdomen are badly preserved; these are expanded and in contact with each other. In the back, the scales are modified in long bars that leave parts of the trunk uncovered. The caudal region seems to be scaleless.

Remarks. Unfortunately, IGM 6618 is a headless specimen, and it is impossible to identify most of the synapomorphies of Pycnodontiformes noted by Poyato-Ariza and Wenz (2002, p. 206). Nevertheless, the inclusion of this specimen into this order is based on three diagnostic characters highlighted by Nursall (1996, p.128-133), the presence of the so named "alate ribs" (= the ribs have anterior and posterior expanded wings), the presence of an anterior sagittal flange in the neural and hemal spines, and the homocercal tail.

Additionally, IGM 6618 shows the synapomorphies defined by Poyato-Ariza and Wenz, (2002) that support its identification as part of the family Pycnodontidae and the subfamily Nursallinae. The occurrence of incompletely ossified, scales at least in the dorsal abdominal part of the trunk, is present in all pycnodontids. The complex interdigitated lateral sutures present in neural and hemal arches are diagnostic of Nursallinae.

Currently, subfamily Nursallinae gathers four genera, Paranursallia Taverne, Layeb, LayebTounsi, and Gaudant, 2015; Abdobalistum PoyatoAriza and Wenz, 2002; and Palaeobalistum Blainville, 1818, as well as Nursallia. Among these fishes, only Nursallia and Paranursallia have the caudal fin vertical (Poyato-Ariza and Wenz, 2002, figure 36; Taverne et al., 2015, p. 222); IGM 6618 is one of one of these genera because it has this 


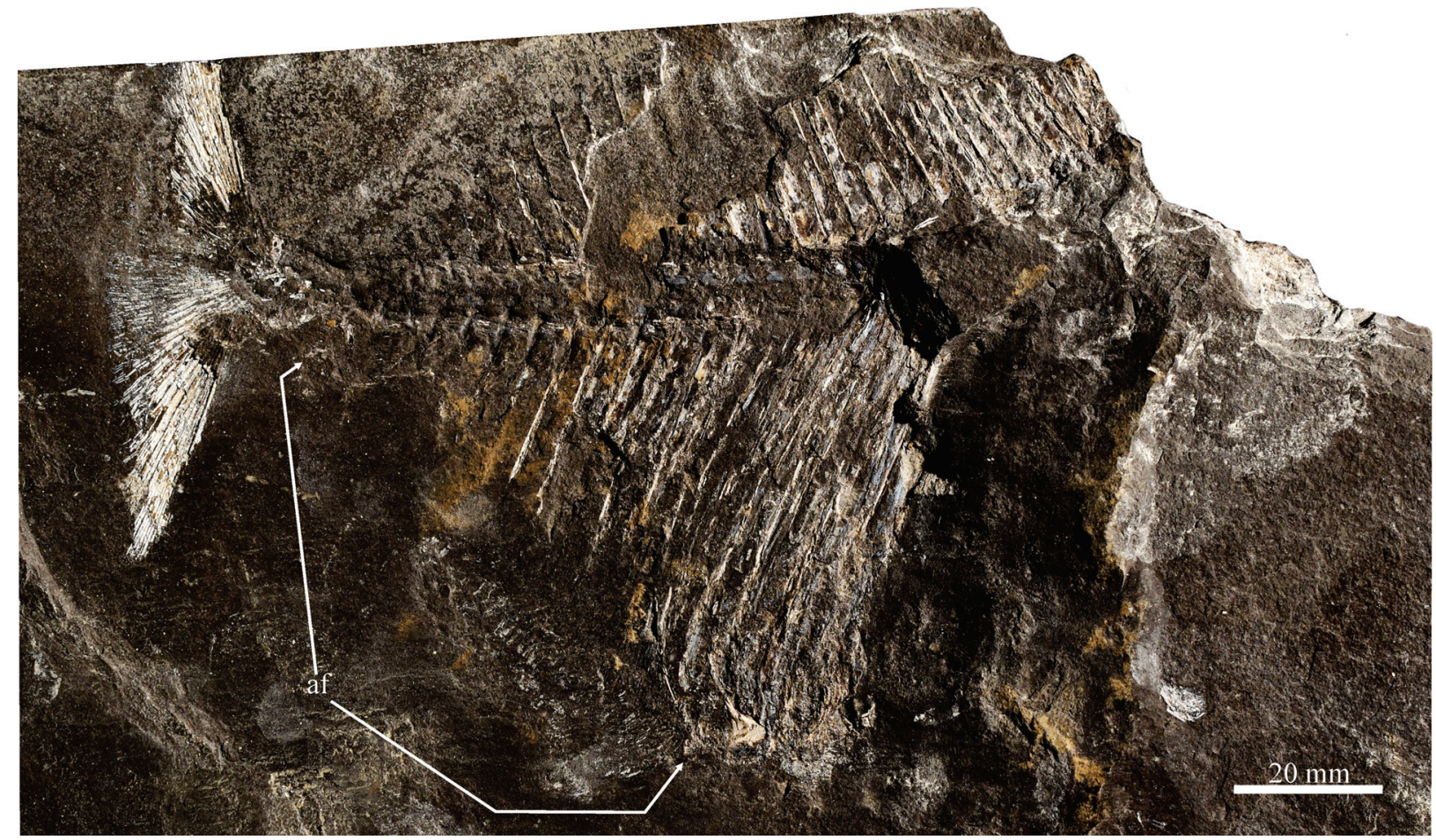

FIGURE 2. IGM 6618, Nursallia cf. N. tethysensis from Huehuetla quarry, Puebla, Mexico. Abbreviations: af, anal fin.

kind of caudal fin (Figure 2). This taxonomical designation also is supported by the presence of neural and hemal arches surrounding the notochord completely, as it occurs in Paranursallia gutturosa and the species of Nursallia.

The morphological differences between Nursallia and Paranursallia are concentrated in the skull, ridge scales, and cloacal scutes, which are not preserved in IGM 6618; however, some meristic characters support the inclusion of this fossil into Nursallia (Table 1). Paranursallia includes two Cenomanian nominal species, the type species $P$. spinosa from Tunisia, as well as $P$. gutturosa (Arambourg, 1954) (previously named as Palaeobalistum gutturosum Blot, 1987, and Nursallia gutturosum Poyato-Ariza and Wenz, 2002) that has a transcontinental distribution from Africa (Jebel
Tselfat, Morocco), Europe (Floresta, Sicily; Cinto Euganeo and Passo del Furlo, Italy), and North America (Mexico and USA) (Kriwet 2005; Shimada et al., 2006; Giersch, 2014; among others). Nursallia gathers the type species, Nursallia veronae Blot, 1987, from the Lower Eocene deposits of Monte Bolca, Italy, as well as two Cenomanian Lebanese species, N. goedeli (Heckel, 1854) [originally described as Palaeobalistum goedeli and now includes $N$. ventralis (Davis, 1887) as a synonymous junior], and $N$. tethysensis Capasso, Abi Saad, and Taverne, 2009 [previously reported as Nursallia sp. by Forey et al. (2003)]. The accurately taxonomical identity of $N$. flavellatum (Cope, 1886) from the Cretaceous deposits of Brazil is very doubtful (Poyato-Ariza and Wenz, 2002; Capasso et al., 2009).

TABLE 1. Comparison of meristic characters of nominal species of Nursallia and Paranursallia; shared characters in boldface.

\begin{tabular}{lcccccc}
\hline & $\begin{array}{c}\text { Nursallia } \\
\text { veronae }\end{array}$ & $\begin{array}{c}\text { Nursallia } \\
\text { goedeli }\end{array}$ & $\begin{array}{c}\text { Nursallia } \\
\text { tethysensis }\end{array}$ & $\begin{array}{c}\text { IGM } \\
\mathbf{6 6 1 8}\end{array}$ & $\begin{array}{c}\text { Paranursallia } \\
\text { gutturosa }\end{array}$ & $\begin{array}{c}\text { Paranursallia } \\
\text { spinosa }\end{array}$ \\
\hline Total vertebrae & $34-35$ & 39 & $31-33$ & $?$ & $34-35$ & 27 \\
Dorsal fin rays & 67 & $\sim 50$ & $58-60$ & $36+$ & $\sim 70$ & $\sim 70$ \\
Anal fin rays & 62 & $\sim 45$ & $\mathbf{5 2 - 5 4}$ & $\sim \mathbf{5 5}$ & $\sim 70$ & $\sim 73$ \\
Principal caudal fin rays & $35-36$ & $26-35$ & $\sim \mathbf{4 0}$ & $\sim \mathbf{4 0}$ & $\sim \mathbf{4 0}$ & $\sim 30$ \\
\hline
\end{tabular}



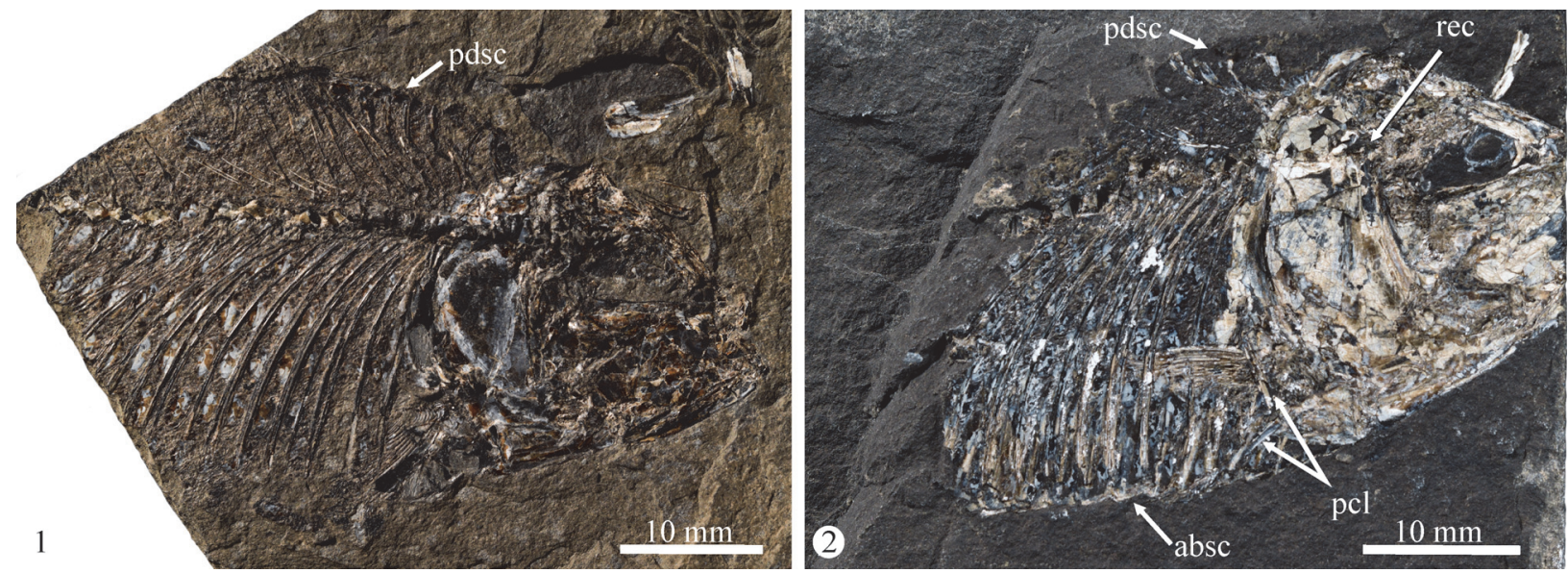

FIGURE 3. Specimens of the family Clupeidae recovered in the Huehuetla quarry, Puebla, Mexico. 1, IGM 6626; 2, IGM 7781. Abbreviations: absc, abdominal scute; pcl, postcleithrum; pdsc, predorsal scute; rec, recessus lateralis.

The number of principal caudal fin rays ranges from 26 to 40 in Paranursallia and Nursallia (Table 1); IGM 6618 has 40 of these rays as in $N$. tethyensis and $P$. gutturosa while other related species have less rays. Additionally, in Paranursallia the anal and dorsal fins are comparative long and consist of $70-73$ and about 70 rays, respectively; contrary, in species of Nursallia these fins are short and involve only 45-62 and 50-67 rays, respectively. The estimated number of anal fin rays of IGM 6618 is 55 , which is close to those 52 to 54 anal fin rays present in $N$. tethysensis; hence, IGM 6618 is recognized as Nursallia aff. tethysensis.

\section{Order CLUPEIFORMES Rafinesque, 1810 sensu Grande, 1985 \\ Family CLUPEIDAE Cuvier, 1817 sensu Grande, 1985 \\ Clupeidae gen. et sp. indet.}

Referred material. IGM 6626, articulated specimen 53 long and $30 \mathrm{~mm}$ high, exposing the right side of the head and the abdominal region (Figure 3.1). IGM 7781, articulated specimen $40 \mathrm{~mm}$ long, exposing the right side and without the anterior tip of the head and the caudal region (Figure 3.2).

Description. Although the caudal part of the trunk is unknown in both specimens; these are deep fishes, in which two thirds of the maximum height of the trunk is occupied by the abdominal cavity. The head is triangular, about equally long than high. Although, most bones of the skull, suspensorium, opercular series, and jaws are broken, all these are smooth. The frontals roof almost all the skull and meet with the supraoccipital bone displacing the parietals to a lateral position. In both specimens, the otic skull region shows a recessus lateralis, an intercranial space where the supraoccipital, infraorbital, preopercular, and temporal sensory canals converge.

The axial skeleton is relatively well-preserved in IGM 6626. This specimen has 17 abdominal centra preserved, which are smooth cylindrical structures slightly constricted in the center. Those centra located just behind the skull are almost square while those placed beyond tend to be more elongated. The ribs are thin curved sticks that enclose almost all the abdominal cavity. The last ribs articulate with the apophysis developed in the most posterior abdominal centra; in front of these, the widened ovoid rib heads articulate directly with the centra. The neural arches are firmly attached to the centra and have simple spines that are elongated, and acute sticks slightly tilted backward. Thin elongated epineurals are attached to the middle part of the neural arches. Thin short epipleurals are projected backward from the articular head of ribs. There are predorsals between the occiput and the dorsal fin base.

In these fishes, the cleithrum is sinuous and has the dorsal and ventral limbs projected vertically. The supracleithrum is oval, attaches the dorsal tip of the cleithrum, and meets the ventral edge of the relatively small posttemporal. IGM 7781 has two elongated rod-like postcleithra. The pectoral fin consists of at least 13 rays of which the most developed are as long as four abdominal centra. This fin is placed at half the height of the abdominal cavity, between the vertebral column and the abdominal edge of the trunk, its length is that of four centra. The anterior part of the dorsal fin preserved in IGM 6626 is supported by 10 pterygiophores and consists of a short anterior unbranched 


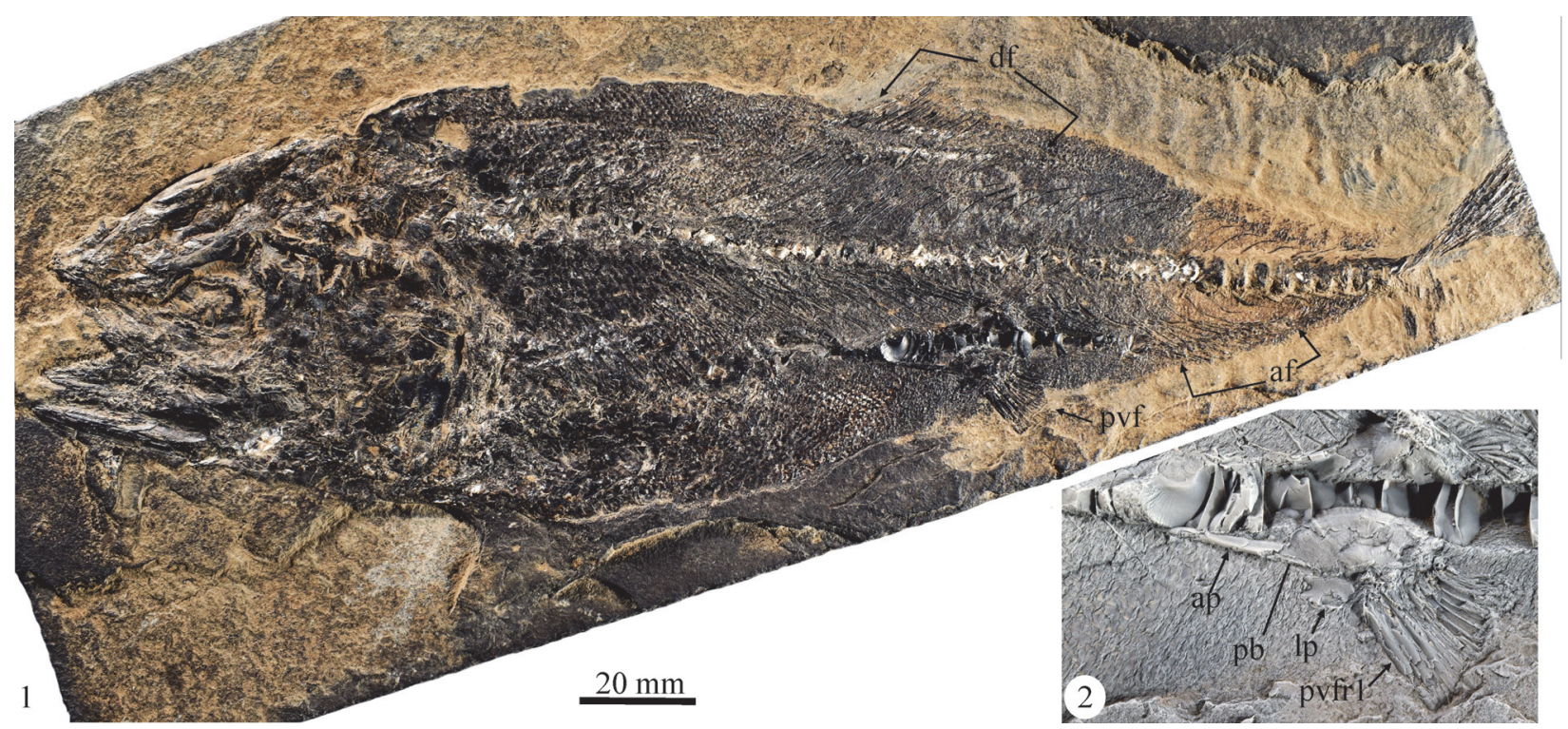

FIGURE 4. IGM 8990, Goulmimichthys roberti from the Huehuetla quarry, Puebla, Mexico. 1, complete specimen; 2 , closeup of the pelvic fin coated with ammonium citrate. Abbreviations: af, anal fin; ap, anterior process of the pelvic bone; df, dorsal fin; Ip, lateral process of the pelvic bone; pb, pelvic bone; pvf, pelvic fin; pvfr, pelvic fin ray.

ray plus seven larger segmented and branched rays.

High ovoid cycloid scales cover the trunk of the referred fishes; these are intensely ornamented with concentric circulli. None of these scales show evidence of the passage of the lateral line along the trunk. Along the ventral edge of the trunk, there is a series of unprecise number of abdominal scutes that are laterally extended covering a quarter of the abdominal cavity. Each abdominal scute has two acute triangular lateral wings, a thickened central keel that protrudes backward forming a blunt tip that overlaps the anterior tip of the subsequent scute. Along the predorsal body edge, there is a series of seven or eight aligned and overlapped scutes; these are thick, ovoid, and smooth structures of similar size with an inconspicuous middle longitudinal thickened keel.

Remarks. The fossils described here have unquestionable diagnostic characters that support their inclusion within the cohort Clupeomorpha, order Clupeiformes, suborder Clupeoidei, and family Clupeidae (see Grande, 1985). They show abdominal scutes as it occurs in all clupeomorphs. Their skulls have the lateroparietal condition and the recessus lateralis, which are diagnostic characters of clupeiforms. These fossils also have predorsal scutes that are smooth and of similar size as in the clupeiforms taxa with this scute series. Additionally, in these fossils the lateral line is lost as in all clupeoid taxa, and there are two elongated poscleithra as in clupeids.
Order CROSSOGNATHIFORMES Taverne, 1989

Family PACHYRHIZODONTIDAE Cope, 1872

Genus GOULMIMICHTHYS Cavin, 1995

Goulmimichthys roberti Blanco and Cavin, 2003

Type species. Goulmimichthys arambourgi Cavin, 1995, from the Lower Turonian deposits of the Akrabu Formation, near Goulmima, eastern Morocco (Cavin, 2001).

Referred material. IGM 8990, a complete articulated specimen with $220 \mathrm{~mm}$ of standard length (SL), preserved in part and counterpart (Figure 4).

Description. This is a torpediform fish with a shallow caudal peduncle. The triangular head is contained 3.5 times in the SL. The maximum height of the body, located between the occiput and the dorsal fin base, is also contained 3.5 times in the SL. The pectoral fin is located near the abdominal edge of the trunk. The pelvic fin is small and opposed to the posterior half of the dorsal fin. Both anal and dorsal fins are acuminated. The dorsal fin is contained 5.5 times in the SL and placed just behind the beginning of the posterior half of the body. The anal fin is contained about eight times in the SL and placed far back in the trunk, behind the dorsal fin and on the posterior fifth of the SL.

The skull bones are smooth. The frontals roof almost all the skull and meet the supraoccipital far back, in the posterior half of the skull, in the otic region where they separate the parietals. The suture between frontals is somewhat sinuous and located at the bottom of the interfrontal depression. 
In the occiput there are five conspicuous posterior projections, the middle thin long supraoccipital crest, two blunt epioccipital processes, and two pterotics processes that are spiny or acute. There are remains of a large extrascapular covering the occiput. Below the ethmoid region of the skull there is a laminar bone, probably the anterior part of the entopterygoid, with numerous small rounded teeth.

The lower jaw joins with the quadrate below the posterior edge of the orbit. The occlusal surfaces of both jaws are straight and bear a single row of small conical teeth slightly curved backward. The vertebral column consists of 28 abdominal, 18 preural, and probably one ural centra. The abdominal region shows elongated straight epineural and epipleural bones associated with the neural spines and ribs, respectively.

The number of pectoral rays is unknown; the pelvic fin consists of 13 rays. The pelvic bone is well exposed; this shows an elongated rod-like anterior process and an expanded ischial region with a well-developed lateral process. The dorsal fin consists of 21 rays supported by 20 pterygiophores. The anal fin consists of 15 or 16 rays supported on 15 pterygiophores. The caudal fin is not well preserved. The body is covered with petite oval cycloid scales strongly ornamented with numerous concentric scales.

Remarks. The order Crossognathiformes is an extinct group erected to unify two previously dispersed Cretaceous taxa, the family Crossognathidae and the suborder Pachyrhizodontoidei (Taverne, 1989). The taxonomical composition and relationships of this order have been enriched through numerous recent studies (Cavin, 1995, 2001; Taverne, 1996; Alvarado-Ortega et al., 2008; Arratia et al., 2018; among others). Although, the development of a comprehensive study of the Crossognathiformes to resolve the disputes between different phylogenetic hypotheses is desirable (Cavin, 1995, 2001; Arratia, 2008; Cumbaa and Murray, 2008); the most comprehensives of these studies suggest that this is a monophyletic group that involves the Jurassic families Varasichthyidae and Chongichthyidae, as well as the Cretaceous families Crossognathidae, Notelopidae, and Pachyrhizodontidae (Arratia and Tischlinger, 2010). Forey (1977) included the last two families in the suborder Pachyrhizodontoidei.

IGM 8990 is a member of the Crossognathiformes because it shows a wide and well-developed extrascapular bone, which is the single synapomorphy of this order (Arratia and Tischlinger, 2010). In IGM 8990, the dorsal fin rises ahead of the pelvic fin as in all the Cretaceous crossognathiforms (Arratia, 2008). This specimen also has a relatively short dorsal fin as the most Cretaceous crossognathiforms (crossognathids, notelopids, and large part of pachyrhizodontids). The synapomorphic value of the short dorsal fin was recently challenged, after the discovery of complete specimens with long dorsal fins as Pachyrhizodus caninus Cope, 1872 (Shimada, 2015) and the inclusion of Tingitanichthys Taverne, 1996, as a true pachyrhizodontid (Cavin, 2001; Giersch, 2014; Arratia et al., 2018). Among the Cretaceous crossognathiforms with long dorsal fins, this is located above and opposed to the pelvic fin, while in Jurassic relatives the dorsal fin is always short, and it is placed above and opposed to the pelvic fin.

Currently, Goulmimichthys Cavin, 1995, differs from other Cretaceous crossognathiforms with short dorsal fins because: 1) the back of the skull has three peculiar structures protruding backward, the thin supraoccipital crest, two blunt epioccipital processes, and two spiny pterotics process; 2 ) the pelvic bone consists of a thin elongated rod-like anterior process, a strongly expanded ischial region, and a well-developed lateral process; and 3 ) the vomer and entopterygoids are covered with patches of minute pointed teeth (Cavin, 1995, 2001). IGM 8990 is an unquestionable member of this genus because it has the first two characters.

Actually, there are three nominal species of Goulmimichthys; the type species G. arambourgi (see Cavin, 1995, 2001); G. gasparinii PáramoFonseca, 2001, from the Lower Turonian deposits of the La Frontera Formation, near Yaguará, Huila, Colombia; and G. roberti Blanco and Cavin, 2003, from the Lower Turonian deposits of the Agua Nueva Formation exploited in the Vallecillo quarry, Nuevo León, northeastern Mexico (also see Giersch, 2014). Table 2 summarizes a morphological comparison of these species. There are 18 caudal vertebrae in IGM 8990 and in the specimens of G. roberti already figured (Blanco and Cavin, 2003, figure 3; Giersch, 2014, figure 4.53); contrary in G. gasparinii these centra are unknown and in $G$. arambourgi these are 26. IGM 8990 and G. roberti share the presence of 13 pelvic fin rays reported by Blanco and Cavin (2003); however, Giersch (2014) claimed that $G$. roberti has 13 to16 pelvic fin rays, a range that includes those 15 pelvic rays observed in G. arambourgi close to the 17 pelvic rays reported in G. gasparinii. The desired revision of this genus should wait for the collection of more specimens from the South American and African 
TABLE 2. Comparison of meristic characters of IGM 8990 and nominal species of Goulmimichthys; shared characters in boldface. Abbreviations: T, total; abd, abdominal; cau, caudal or preural; u, ural.

\begin{tabular}{lcccc}
\hline & G. arambourgeri & G. gasparinii & G. roberti & IGM 8990 \\
\hline Vertebrae $(\mathrm{T}=\mathrm{abd}+\mathrm{cau}+\mathrm{u})$ & $51=23+26+1$ & $?=?+?+?$ & $\mathbf{? = ? + 1 8 + 1}$ & $\mathbf{4 7 = 2 8 + 1 8 + 1}$ \\
Pectoral fin rays & $\mathbf{1 5}$ & $\mathbf{1 7 - 1 9}$ & $\mathbf{1 5 - 1 7}$ & $?$ \\
Pelvic fin rays & 13 & 17 & $\mathbf{1 3}$ & $\mathbf{1 3}$ \\
Dorsal fin rays & $?$ & $?$ & $\mathbf{2 1}$ & $\mathbf{2 1}$ \\
Anal fin rays & $?$ & $?$ & 16 & $15-16$ \\
\hline
\end{tabular}

species. Although weak, considered the actual scenario, it is possible to conclude that the number of caudal vertebrae and pelvic fin rays support the taxonomical determination of IGM 8990 as a member of the Mexican species, G. roberti.

\section{Order AULOPIFORMES Rosen, 1973 \\ Family DERCETIDAE Pictet, 1850 \\ Genus HASTICHTHYS Taverne, 1991 \\ Hastichthys sp.}

Type species. This is a monotypic genus that includes Hastichthys gracilis (Chalifa, 1989), firstly described as Rhynchodercetis gracilis, from the Lower Cenomanian of the Amminadav Formation, in Ein-Yabrud, Cisjordania, Palestine.

Referred material. Two specimens are referred to this genus (Figure 5). IGM 7969, complete articulated specimen exposing the left side with $100 \mathrm{~mm}$ of SL (Figure 5.1, 5.4). IGM 7970, head exposing the skull roof and the pectoral girdle (Figure 5.2, 5.3).

Description. This is a longirostrine fish with a thin elongated and uniformly shallow trunk. The tail is homocercal and slightly forked. The positions of pelvic and anal fins are unknown. The dorsal fin is short and located in front of the middle point of the trunk, but it rests in the posterior half of the SL. In IGM 7969 the head length (including the opercle) is contained three times in the SL, and the height of the skull is contained six times in the head length. The snout is formed by the elongation of the mesethmoid and the supramaxillae. The skull, almost entirely roofed by the frontals, displays the lateroparietal condition because the supraoccipital and the frontal meet in the middle part of the otic region. The articulation between the lower jaw and the quadrate is far back, behind the orbit and opposed to the middle part of the skull. The jaws are elongated but the length of the lower jaw is about the same length as the outgoing part of the upper jaw. There is a row of small conical teeth slightly curved backward in the maxilla and the dentary, while the premaxilla is toothless. The surface of the maxilla seems to be smooth while the dentary and premaxilla are ornamented with conspicuously longitudinal ridges. The opercle is $D$ shaped and slightly longer than high. The pectoral fin rises just below the vertebral column. The total number of vertebrae is 55 (the number of abdominal and caudal centra is not clear); along the trunk, the neural arches are shallow but slightly longer than the respective centra. The neural spines are small and shorter than the neural arches. The abdominal centra have two triangular transverse processes, of which the anterior one is larger than the posterior. An undetermined number of elongated predorsal (= supraneural) bones rest above the eight abdominal centra located behind the opercle. In the caudal skeleton the suture between the hypurals 2 and 3 are sinuous or convolute; the hypural 1 is fused with hypural 2 while the hypural 3 is fused at least with the hypural 4. The trunk seems to be entirely nude, with no scales.

Remarks. Goody (1969) stated that Dercetidae includes Dercetis Muster and Agassiz, 1843 (in Agassiz, 1843a, p. 258), and two allied genera. Since then, systematic studies show that this family is into the core of the order Aulopiformes (Taverne, 1987, 1991, 2006). The phylogenetic study of Silva and Gallo (2011, p. 486 and figure 1), shows Dercetidae as a monophyletic group of 13 genera sharing two synapomorphies, the opercle has no posterior spine, and the neural spines are comparatively small. Posterior studies (Díaz-Cruz et al., 2016; Vernygora et al., 2017) reveal similar conclusions, but in these the family is supported only on the second character. The specimens referred here are dercetids because they have both characters.

Díaz-Cruz et al. (2016) and Vernygora et al. (2017) found that the convolute suture between the hypurals 2 and 3 is a synapomorphy of an unnamed subgroup within Dercetidae, in which Caudadercetis Taverne, 2006, is the basal member. Although, interrelationships into this unnamed subgroup are still problematic; the inclusion of Candelarhynchus padillai Vernygora, Murray, Luque, Ruge, and Fonseca, 2017, from lower-middle Turonian deposits of the San Rafael Formation, 

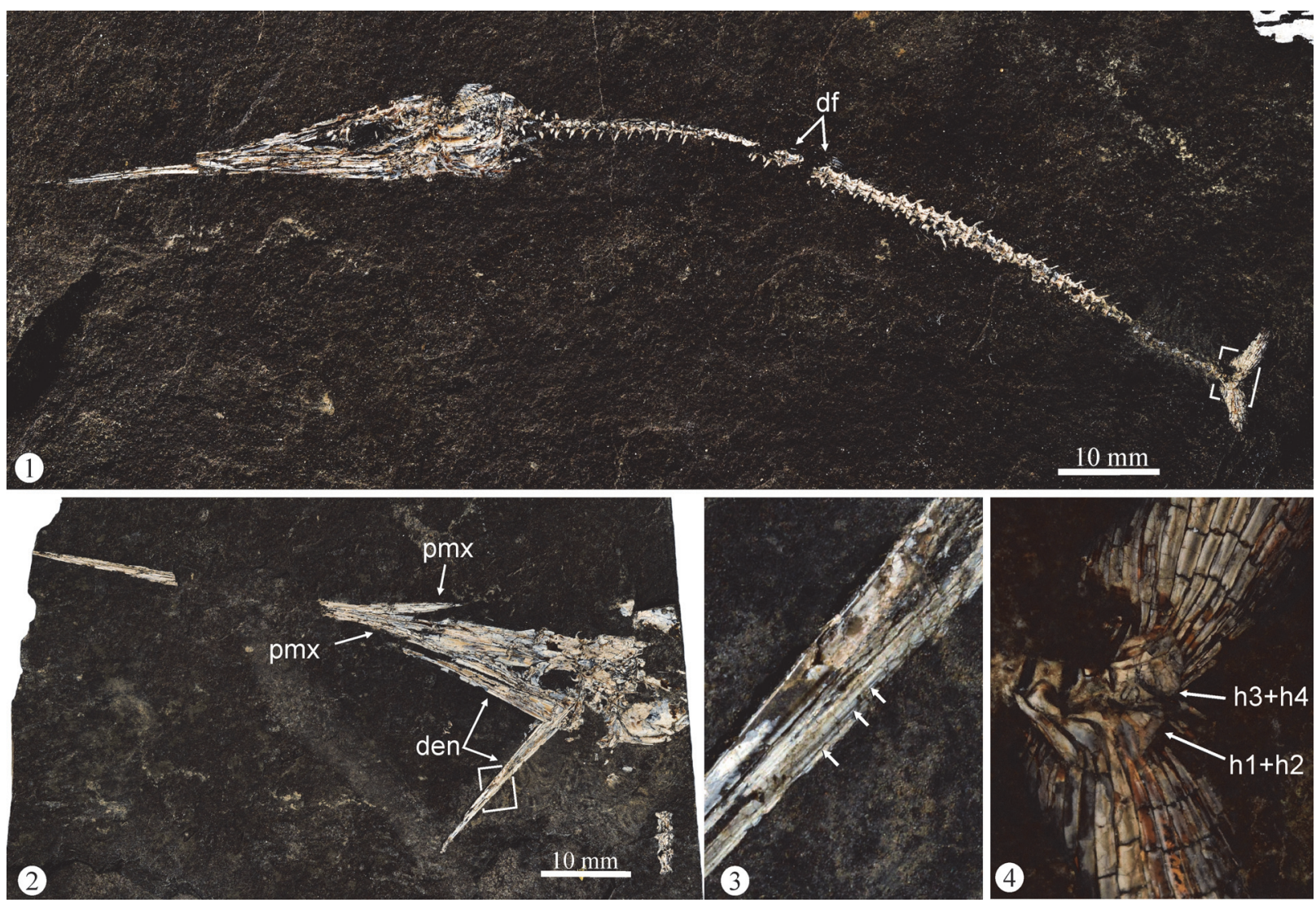

FIGURE 5. Hastichthys sp. from the Huehuetla quarry, Puebla, Mexico. 1, IGM 7969, a complete specimen; 2, IGM 7970, a specimen showing bones of the head and some vertebrae; 3, closeup of the lower jaw (= square in 2); 4 , closeup of the caudal fin (= square in 1). Abbreviations: den, dentary; df, dorsal fin; $h$, hypural; pmx, premaxilla; the arrows in 3 show the longitudinal ridges in dentary bone that are like those observed in the premaxilla.

Colombia, in the phylogenetic study of Dercetidae shows that Candelarhynchus and Hastichthys form part of an unnamed and the most derived subgroup within this family. These two genera share four characters (Vernygora et al., 2017, p. 11, node D in figure 1 of supplement 1): 1) the posttemporal fossa roofed; 2) the lateroparietal condition of the skull; 3) the premaxillae ornamented with longitudinal ridges; and 4) the toothless premaxillae (see Taverne, 1991; and Vernygora et al., 2017). Specimens referred here belong to this Hastichthys-Candelarhynchus subgroup because they have the last three characters.

Hastichthys differs from Candelarhynchus in three characters. In Hastichthys the abdominal centra have two transverse processes, the premaxillae are extremely long (the outgoing part of the premaxilla is about as long as the lower jaw), and a row of minute triradiate scutes covers each flanks of trunk. Contrary, in Candelarhynchus the precaudal centra have only one transverse process, the premaxillae are comparatively short (the outgoing part of the premaxilla is contained at least three times in the lower jaw), and the trunk is nude. Although, the nude trunks of the specimens referred here and that of Candelarhynchus could be an artifact of the preservation; these Mexican specimens are identified as part of Hastichthys because they have two transverse processes on the abdominal centra and an extremely elongated maxilla.

Hastichthys gracilis is the single species of Hastichthys. This species has 71 total vertebrae Therefore, the 55 total vertebrae are a common diagnostic character of a potential new Mexican species of Hastichthys. Today, the formal description of a new Hastichthys species based on the present referred specimens, and other abundant fossils from the Huehuetla quarry is in progress. This is the first report of Hastichthys all over America, which extends the geological and geographical distribution of the genus, from the Cenomanian in the Middle East to the Turonian in North America. 


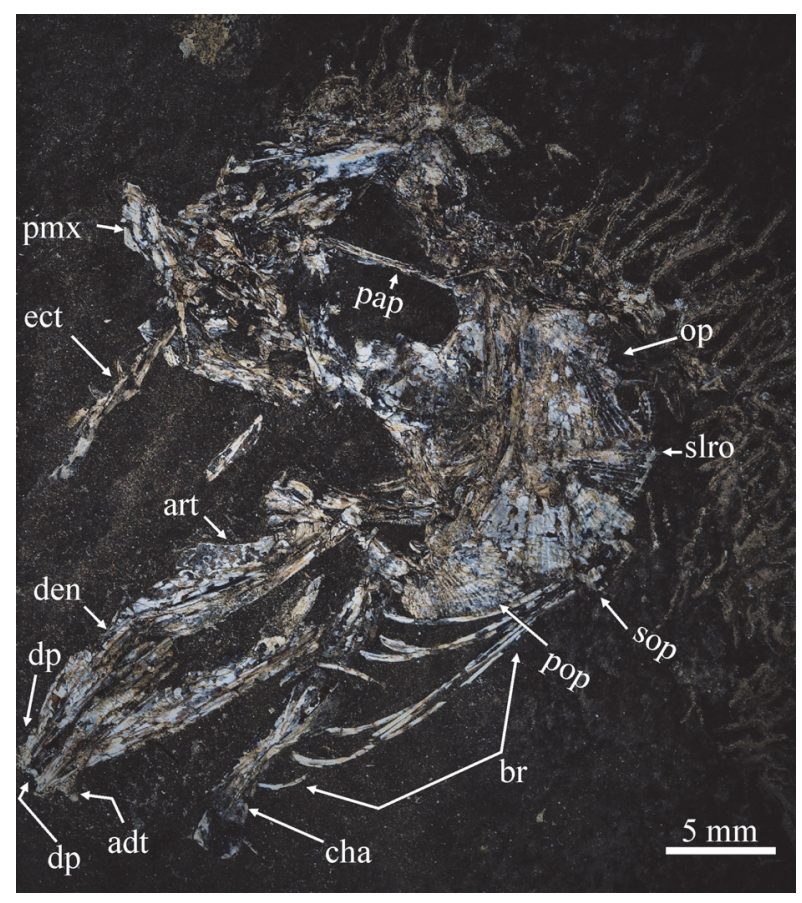

FIGURE 6. IGM 8991, Enchodus sp. from the Huehuetla quarry. Abbreviations: adt, anterior dentary tooth; art, articular, br, branchiostegal ray; cha, anterior ceratohyal; den, dentary; dp, dentary prongs; ect, ectopterygoid; pap, parasphenoid; pmx, premaxilla; op, opercle; pop, preopercle; slro, strengthened longitudinal ridge of the opercle (=longitudinal straight bar of the opercle); sop, subopercle.

\section{Family ENCHODONTIDAE Woodward, 1901 sensu Fielitz, 2004 \\ Genus ENCHODUS Agassiz, 1843b Enchodus sp.}

Type species. Enchodus lewesiensis (Mantell, 1822), Turonian and Senonian sediments of the Middle Chalk in Lewes, Sussex, southeastern England (see Goody, 1969).

Referred material. IGM 8991, disarticulated bones of the head and opercular series of one specimen (Figure 6).

Description. The partial head length in IGM 8991 is about $40 \mathrm{~mm}$. Most of the bones preserved in this specimen are bad preserved. Part of the premaxilla rests below the ethmoid part of the skull; this bone seems to be smooth and triangular. No premaxilla bones are preserved. Part of the ectopterygoid is preserved showing a row of stout conical teeth.

The lower jaw is an elongated triangular structure with a shallow symphysis. The articular and dentary bones of both lower jaws are unattached. The straight alveolar surface of each dentary bears a row of conical teeth (preserved as impressions), including the anterior one that is the longest in the series. A short series of three or two prongs in the anterior end of the ventral edge of the dentary.

The opercular series includes the opercle, subopercle, and preopercle. The opercle is a kidney-shaped bone, with the posterior border harmoniously convex and a longitudinal bar or strengthening ridge. The subopercle is semicircular with the dorsal border straight. The preopercle is somewhat triangular with the posteroventral section expanded. All these bones are intensely ornamented with radiating ridges. The anterior ceratohyal is long and unperforated. At least eight long and thin branchiostegal rays are preserved.

Remarks. Currently, the family Enchodontidae is considered a monophyletic extinct group of marine active predator fishes that includes five genera (Díaz-Cruz et al., 2016). Within the family, the genus Enchodus erected by Agassiz (1843b, p. 64) is the most diverse and successful genus. This gathers about 70 nominal species, and its fossils have been recovered in Upper Albian-Eocene deposits distributed in practically the whole world (Woodward, 1901; Goody, 1969; Alvarado-Ortega et al., 2009; Fielitz and González-Rodríguez, 2010, among others). The interrelationships of enchodontids have been addressed in recent phylogenetic studies (Fielitz, 2004; Silva and Gallo, 2011; Cavin et al., 2012; among others).

In the most recent phylogenetic studies of Enchodontidae, the monophyly of the family is supported on three synapomorphies, the occurrence of a predorsal scute series, the lack of the supraorbital bone, and the prominent strengthening longitudinal ridge or bar in the opercle (i.e., Silva and Gallo, 2011; Díaz-Cruz et al., 2016). IGM 8991 is identified as a member of this family because it shows the opercular bar. This specimen also is identified as a member of Enchodus because the opercular bones are strongly ornamented with longitudinal ridges, the posterior border of the opercle is harmoniously rounded and does not have any spine, the posterior ventral section of the preopercle is somewhat expanded, and the anterior tip of the lower jaw displays dentary prongs. Among enchodontids, this group of characters is only present in Enchodus (Díaz-Cruz et al., 2016).

In Mexico, fossil of Enchodus have been collected in Albian-Maastrichtian deposits of Coahuila, Tamaulipas, Nuevo León, San Luis Potosí, Hidalgo, Guerrero, Chiapas, and Puebla (CarbotChanona and Than-Marchese, 2013; GonzálezRodríguez et al., 2016; among others). IGM 8991 


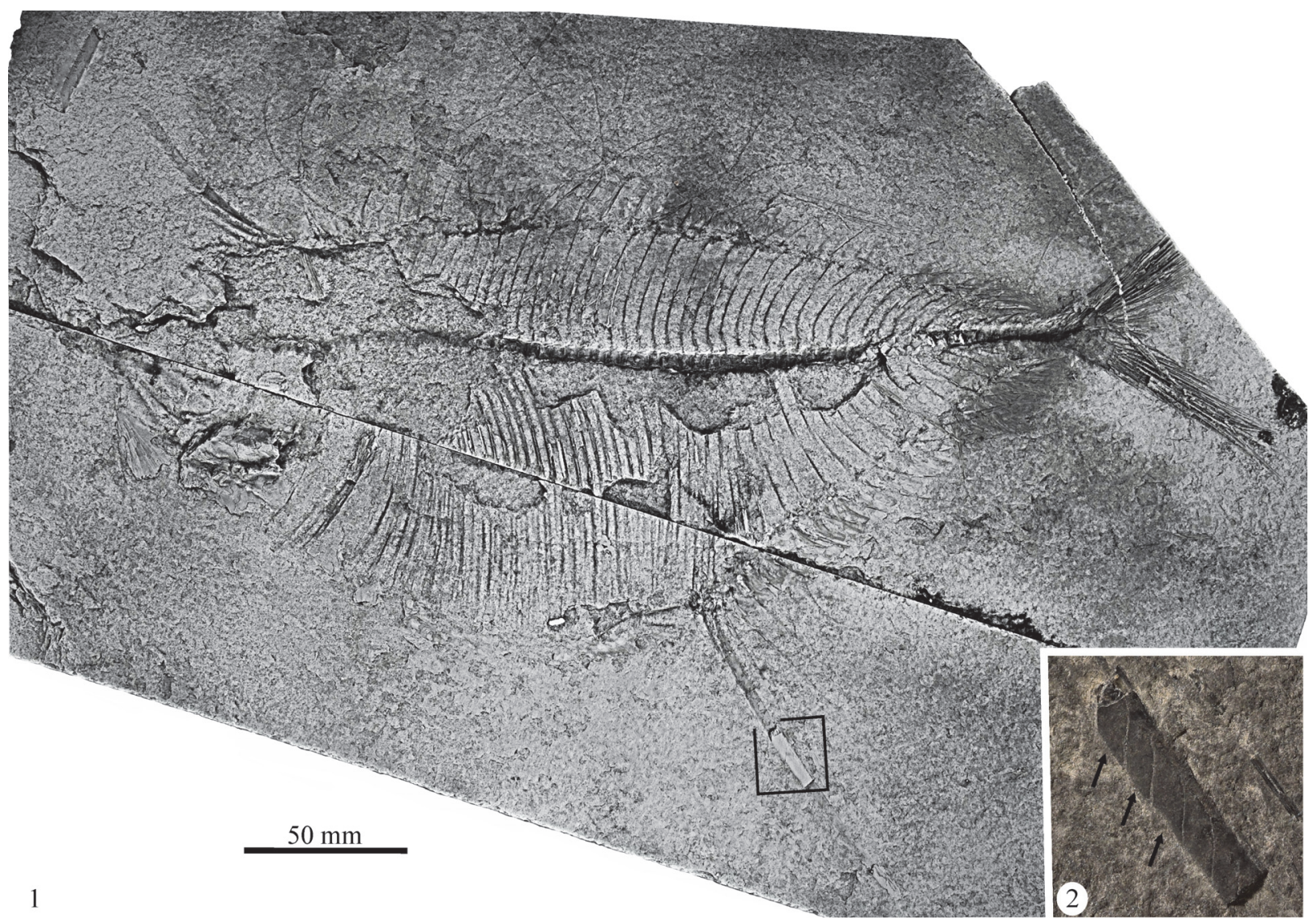

FIGURE 7. IGM 9524, Tselfatia formosa from the Huehuetla quarry, Puebla, Mexico. 1, complete specimen coated with ammonium citrate; 2 , closeup of fulcra in the longest anal fin ray indicated by black arrows (= square in 1).

is the first report of Enchodus in the northern region of Puebla.

Order TSELFATIIFORMES Nelson, 1994

Family PLETHODIDAE Loomis, 1900 sensu

Taverne and Gayet, 2005

Genus TSELFATIA Arambourg, 1943

Tselfatia formosa Arambourg, 1943

Referred material. IGM 9524, complete specimen of $160 \mathrm{~mm}$ of SL, preserved in two parts and almost entirely as an impression (Figure 7).

Description. Since the large part of the body of IGM 9524 is preserved as impression, little can be described of its anatomy. This is an oblong fish with a shallow caudal peduncle and high body, in which the dorsal and ventral edges are curved, being the last more prominent. The maximum height of the body is near to the middle of the body. Two and a half measures of this height could be contained in the SL. The head is triangular with slightly convex edges. Three and a half measures of this length could be contained in the SL, and its maximum height is about 1.5 times in the maximum body height. The gular plate is triangular and orna- mented with fine longitudinal grooves. The vertebral column consists of about 55 cylindrical vertebrae, including 37 abdominal and 26 caudal. The neural and hemal spines are long simple structures progressively tilted backward. Long epineurals are above the anterior two thirds of the abdominal vertebrae. There are no epipleurals. The ribs are thin, curved, and long and practically enclose the abdominal cavity.

Nothing can be said about the pectoral fin except for its vague impression just below the vertebral column. The small pelvic fin is about at the middle of the SL near the anal fin origin. The dorsal fin occupies practically all the dorsal edge of the trunk, from the occiput to the north and shallow caudal peduncle. The anal fin is also long and rises behind the middle of the SL. The dorsal fin consists of about 38 rays distally fragmented; among these the fourth one is noticeable because it is segmented and anteriorly bordered with stout rhomboidal pseudo-fulcra, four times longer than high. The anal fin consists of about 28 distally branched rays; 
in which the third one also is segmented and bordered by stout pseudo-fulcra.

The caudal fin consists of two deeply forked lobes of similar shape and size. The caudal skeleton has a huge triangular hypural plate incompletely preserved that perhaps involves the fusion of the first four hypurals. Hypurals 2 and 3 are partially fused, but they are in contact all along showing a straight longitudinal suture in the middle of a shallow and narrow groove. The hypural 5 is a rectangular free bone located above the hypural plate. A longitudinal ridge is projected along the middle longitudinal axis of the most posterior three or four preural centra. The parhypural is robust and lacks prezygapophysis.

The few scales conserved in IGM 9524 reveal that these are cycloid and ovoid, higher than long. In these scales the focus is in the center, the anterior region is ornamented with numerus concentric circuli, and the posterior region is rather smooth and topped with a deeply pectinate posterior edge. At least one row of scales covers the base of the anal and dorsal fin rays.

Remarks. According Taverne and Gayet (2005), the order Tselfatiiformes is a monophyletic group of teleosts. IGM 9524 displays five diagnostic characters supporting its inclusion into this order; these are the high and compressed body, the long dorsal and anal fins extended up to the caudal peduncle, the presence of rays branched and unsegmented in the dorsal and anal fins, the lack of ossified epipleurals, and the presence of an hypural plate that results of the fusion of hypurals 3 and 4 .

Currently, the order Tselfatiiformes includes three families, Protobramidae, Eoplethodidae, and Plethodidae (Taverne and Gayet, 2004, 2005). Among these, the protobramids have a distinctive hemal spines that have anterior laminar wing and the eoplethodids have a conspicuous prezigoapofisis in the parhypural. IGM 9524 cannot be included as a protobramid nor eoplethodid because it does not possess any of such diagnostic features. Contrary, IGM 9524 is identifiable as a plethodid because its pectoral fin is located high in the flank of the trunk, close to the vertebral column, and the longitudinal groove in the hypural plate is inconspicuous, which are diagnostic characters of the family Plethodidae.

The family Plethodidae includes 17 genera and about 27 species making of this the most diverse and derived tselfatiiform group. Among these fishes, the longest anterior dorsal and anal fin rays are segmented and bear an anterior row of pseudo-fulcra only in the genera Tselfatia and Dix- onanogmius Taverne, 2000b. The pseudo-fulcra are longer than high trapezoidal structures, which in the case of Dixonanogmius are comparatively elongated and graceful, about four times longer than high, while in Tselfatia the pseudo-fulcra are stout, about two times longer than high. Here IGM 9524 is considered as a member of Tselfatia because its first large anal and dorsal fin rays are associated with stout pseudo-fulcra. Additionally, IGM 9524 is covered with cycloid scales with deep pectinated posterior border as it occurs in Tselfatia (Arambourg, 1954; Bardack and Teller-Marshall, 1980; Taverne, 1983, 2000a; Giersch, 2014, figures 4.89, 4.93, 4.94; Taverne and Liston, 2017, figure 7; among others). Tselfatia is a monospecific genus represented by T. formosa. Here, IGM 9524 is referred to $T$. formosa because its body proportions and osteological details are like those of this species (Taverne, 1983; Maisch and Leheman, 2000). IGM 9524 is the first specimen of T. formosa recovered in Turonian deposits of Puebla.

Order SQUAMATA Oppel, 1811

Superfamily MOSASAUROIDEA Gervais, 1853 Mosasauroidea family indeterminate

Referred material. IGM 9525, 95 mm long terminal fragment of the tail with 25 vertebrae (Figure 8). Description. Overall, the size of vertebral centra and the respective neural and hemal components is anteroposteriorly decrescent. The centra are procoelous and cylindrical; the sixth most anterior centra are rectangular, slightly longer than high, but those located behind tend to be as long as they are high. Some vertebrae seem to have short prezygapophyses and postzygapophyses extended anteriorly and posteriorly from the base of the neural arches; certainly, the most posterior five centra lack these processes. Only the most anterior 3 or 4 caudal vertebrae preserved display inconspicuous triangular transverse processes. The join between chevron and the transverse processes is in the posterior half of each centrum.

The neural spines of the posterior 24 vertebral centra are preserved. These are rectangular structures, about three times higher than long, slightly constricted at the base, and tilted backward. The borders of these spines are straight except in the posterior one that is somewhat curved. The width of these spines is close to twothirds of its respective vertebral center. The most anterior neural spines preserved are strongly tilted backward, their main axis forms an acute angle of about 30 to 35 degrees with the vertebral column; hence, these roof the subsequent vertebral centrum. Towards the back of the tail, the neural 


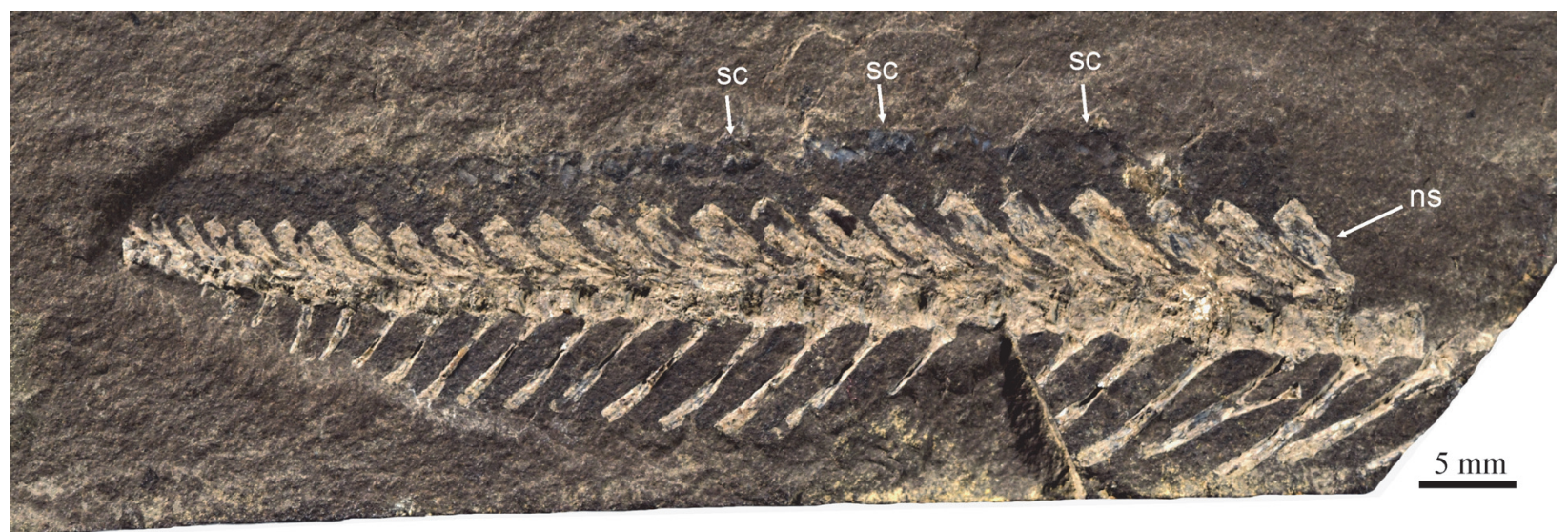

FIGURE 8. IGM 9525, tail of a mosasaur from the Huehuetla quarry, Puebla, Mexico. Abbreviations: ns; neural spine; sc, scales.

spines tend to be less inclined, forming larger angles with the vertebral column, and extending less over the posterior centrum.

In the four most anterior centra there is no associated chevrons. Anteriorly, all vertebrae have chevrons, but these are not fused. In these elongated Y-like bones the distal end is expanded, and the arch is narrow and occupies one-third of the bone length. The anterior chevrons are almost four times longer than their respective vertebral centra and are strongly tilted backward, forming angles close to 45 degrees. Toward the back of the tail, the chevrons tend to be shorter and less tilted. The shape of this tail is delineated around the caudal skeleton, where the texture and the superficial color of the carrier rock are clearly distinguishable, because the rhomboid scales that once enclosed it are preserved as vague impressions or by strongly recrystallized remains of black color.

Remarks. The procoelous and cylindrical vertebrae preserved in IGM 6525 show that it belongs to the Squamata. Within this order, the superfamily Mosasauroidea is an extinct group of cosmopolitan successful marine reptiles that lived in the oceans and epicontinental seas from the Late Cenomanian to Maastrichtian (Jiménez-Huidobro et al., 2017). Two diagnostic characters of Mosasauroidea present in IGM 9525 are the occurrence of zygapophyses and reduced transverse processes in the caudal vertebrae (Caldwell and Bell, 1995). Despite the incompleteness of IGM 9525; this is located into this superfamily because it has these characters. Unfortunately, this Mexican specimen does not show enough characters to improve this taxonomical determination.

\section{DISCUSSION}

The geological maps show that Huehuetla quarry occupies an area where a Middle-Aptian to Cenomanian undifferentiated outcrop is present, which probably involves the Tamaulipas Inferior Formation, the Otates Horizon, and the Tamaulipas Superior Formation (Servicio Geológico Mexicano, 2004). The lithological composition of rocks from the Huehuetla quarry reveals that these do not match with those geological units previously recognized in this Mexican region. Contrary, the fossiliferous strata of Huehuetla consist of black carbonated shales and jet-black laminated marly limestones with fine flit horizons and microscopic pyrite crystals, which resemble those Late Cenomanian-Turonian strata of the Agua Nueva Formation (Figure 1). The faunistic association recovered in Huehuetla also represents a remarkable regional discovery. It is desirable to plan future geologicalpaleontological prospections in the mountain region of Puebla to delimit the extension of these fossiliferous strata as well as their spatial relation with other geological units around Huehuetla.

The Vallecillo and Xilitla quarries (Blanco et al., 2001; Maldonado-Koerdell, 1956) are also Turonian outcrops of the Agua Nueva Formation. Although, the comparison of faunas recovered in Xilitla and Huehuetla is not possible because the fossils from the first site are still pending; the fossil assemblages recovered in the Vallecillo and Huehuetla quarries have common faunistic elements that extend the known geographic distribution of different taxa into this country and confirm the Turonian age of the Huehuetla quarry (Figure 9). These common taxa are Goulmimichthys roberti, Tselfatia formosa, and perhaps Nursallia. 


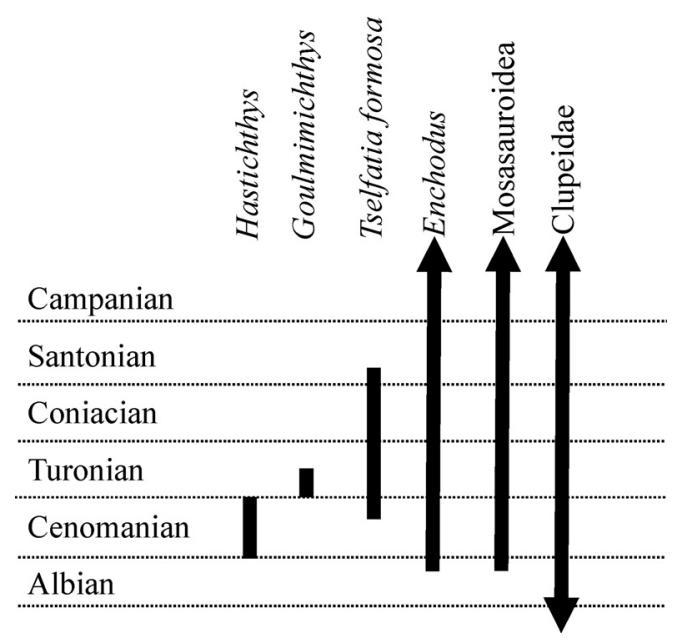

FIGURE 9. Previous global stratigraphical ranges of the taxa found in the Turonian strata of the Huehuetla quarry, Puebla, Mexico.

Goulmimichthys roberti, described based on specimens recovered in the Turonian deposits of Vallecillo, together with G. arambourgi and G. gasparinii, from Morocco and Colombia, constitute an unquestionable monophyletic group (Cavin, 1995, 2001; Páramo-Fonseca, 2001; Blanco and Cavin, 2003). Although Goulmimichthys has a wide distribution on both sides of the paleo-Pacific and in the extremes of America; the temporal distribution of the three species is strictly limited to Turonian. Therefore, the presence of G. roberti in the Huehuetla quarry suggests the Turonian age of this site.

Tselfatia formosa is a Late Cenomanian-Santonian marine species (Arambourg, 1954; Sorbini, 1976; Bardack and Teller-Marshall, 1980; Taverne, 1983; Maisch and Lehmann, 2000; among others). In contrast to the case of Goulmimichthys, once, the spatial and temporal distribution of the monospecific genus Tselfatia showed a pattern. Based on that pattern, it was suggested that Tselfatia originated during the Cenomanian into the Euroafrican domains of the Tethys and later these dispersed toward the west arriving at America in the Coniacian (Maisch and Lehmann, 2000). Previously, fossils of this fish have been collected in Late Cenomanian-Early Turonian deposits of Morocco, Italy, Croatia, and Germany, as well as in the Coniacian-Santonian deposits of the Austin Formation, in Texas, USA. The occurrence of Tselfatia in Mexican fossiliferous sites, including the Huehuetla quarry, contrasts with the previous hypothesis because it proves the presence of this species in the northern region of the Gulf of Mexico and the southern mouth of the North America Interior Sea- way from probably since the Late Cenomanian and certainly since the Early Turonian. Recently, Tselfatia has been also collected in Turonian deposits of distant localities along Mexico, which include the Cenomanian or Turonian deposits of Sierra de Arteaga near Saltillo, Coahuila; the Turonian sites of the Las Bocas quarry in the southern state of Guerrero, the Xilitla quarry in San Luis Potosí, and the La Mula and Vallecillo quarries in the northern states of Coahuila, and Nuevo León, respectively (Blanco et al., 2001; Blanco-Piñón, 2003; BlancoPiñón et al., 2006; Alvarado-Ortega et al., 2006a, 2006b; Giersch et al., 2008; Giersch, 2014; González-Rodríguez et al., 2016).

After the recent description of Paranursallia and the consequently taxonomical rearrangement of Nursallia (Taverne et al., 2015), it is desirable to accurately study all the fossils previously reported as Nursallia in México and USA, in order to clarify if they belong to this genus or to Paranursallia. These specimens include those recovered in the Cenomanian to Turonian deposits of the Sierra de Arteaga region, and in the Vallecillo and La Mula quarries, in Coahuila and Nuevo León, Mexico (Blanco et al., 2001; Giersch et al., 2008; among others); as well as the isolated teeth from the Middle Cenomanian deposits of the Lowermost Greenhorn Limestones and the Turonian bone-bed of Delta County, both in Colorado, USA (Kriwet 2005; Shimada et al., 2006). It is remarkable that in complete specimens from the Vallecillo quarry already illustrated, the anal fins consists of a relatively low number of rays, probably between 50 and 60 (e.g., Blanco-Piñón, 2003, p. 89 and figure 8.5; Giersch, 2014, figure 4.30); this data suggests that at least some of these specimens are true members of Nursallia (in which the anal fin rays range between 52 and 62) and must be relocated far from Paranursallia gutturosa previously known as Nursallia gutturosa (whose anal fin consists of 70 rays) (Table 1). IGM 6618 is reported as $N$. aff. thethyensis because it shows characters of this species.

Currently, Nursallia is a Cenomanian-Eocene pycnodontiform fish that gathers three species, $N$. veronae from the Eocene of Italy and two Cenomanian species from Lebanon, $N$. goedeli and $N$. tethysensis (Capasso et al., 2009). Regarding the present context, the Mexican specimen IGM 6618 confirms the widespread distribution of this genus in America, beyond the Euroafrican region, and the potential younger member of the species $N$. tethysensis within the Turonian.

The presence of Enchodus sp. in Huehuetla is insignificant to determine the age of this locality 
because the temporal distribution Enchodus ranges between Upper Albian and Eocene (Fielitz and González-Rodríguez, 2010). This also occurs with the mosasauroid and the clupeid specimens of Huehuetla because these represent taxa of wide temporal ranges (Jiménez-Huidobro et al., 2017; Grande, 1985). The presence of Hastichthys in Huehuetla is a valuable discovery that expands the temporal and geographical distribution of this fish, from the Cenomanian of the Middle East (Chalifa, 1989) to the Turonian of Mexico.

\section{CONCLUSIONS}

The Turonian fossiliferous site of the Huehuetla quarry, Puebla, Mexico, represents an outcrop of carbonated shales belonging to the Agua Nueva Formation. Additional paleontological data are required to support the age of this site designated in this work, mainly based on the microfossils. Since this is a small site, additional prospects are desirable to recognize the stratigraphical relationships of the Huehuetla strata within the regional geology of Puebla. The vertebrate fossil assemblage here described resembles other coeval fossil associations recovered in Mexico, mainly those from the Vallecillo quarry. Important taxa are reported in this paper, as the first occurrence of Nursallia aff. tethysensis and Hastichthys all over America, the first specimen of Tselfatia formosa recovered in Puebla, and the most complete specimen of Goulmimichthys roberti.

\section{ACKNOWLEDGMENTS}

The authors thank F. Aranguthy and his father $R$. Aranguthy for letting us study the fossils from the Huehuetla quarry. J.M. Contreras helped us with the photographs of this work. S.P. Ordaz prepared the fossils studied here. Financial support of this project was provided by the UNAM through grants DGAPA-PAPIIT IN106011, IN207314, and IN 209017; CONACyT provided additional individual financial support granted to JIBL, JADC, and BATM.

\section{REFERENCES}

Agassiz, L. 1833. Recherches sur les Poissons fossils. Tome I. Petitpierre, Neuchâtel and Soleure (dated as 1833-1843, with préface of 1833).

Agassiz, L. 1843a. Recherches sur les Poissons fossils. Tome II. Petitpierre, Neuchâtel and Soleure (dated as 1833-1843, with préface of 1843).

Agassiz, L. 1843b. Recherches sur les Poissons fossils. Tome V. Petitpierre, Neuchâtel and Soleure (dated as 1833-1843, with préface of 1843).

Alvarado-Ortega, J., Cantalice, K.M., Díaz-Cruz, J.A., Castañeda-Posadas, C., and ZavaletaVillareal ,V. In press. Vertebrate fossils from the San José de Gracia quarry, a new Late Cretaceous marine fossil site in Puebla, Mexico. Boletín de Sociedad Geológica Mexicana.

Alvarado-Ortega, J., Garibay-Romero, L.M., Blanco-Piñón, A., González-Barba, G., Vega-Vera, F.J., and Centeno-García, E. 2006a. Los peces fósiles de la Formación Mexcala (Cretácico Superior) en el Estado de Guerrero, México. Revista Brasileira de Paleontología, 9:261-272.

Alvarado-Ortega, J., González-Rodríguez, K.A., Blanco-Piñón, A., Espinosa-Arrubarrena, L., and Ovalles-Damián, E. 2006b. Mesozoic Osteichthyans of Mexico, p. 169-207. In Vega, F.J., Nyborg, T.G., Perrilliat, M.C., Montellano-Ballesteros, M., Cevallos-Ferriz, S.R.S., and Quiroz-Barroso, S.A. (eds.), Studies on Mexican Paleontology. Topics on Geobiology, 24. Springer, Dordrecht, The Netherlands.

Alvarado-Ortega, J., Mayrinck, D., and Brito, P. 2008. A basal pachyrhizodontid fish (Actinopterygii, Teleostei) from the Lower Cretaceous of the Tlayúa Quarry, Central Mexico. Comptes Rendus Palevol, 7:269-275. https://doi.org/10.1016/j.crpv.2008.03.006

Alvarado-Ortega, J., Ovalles-Damián, E., and Blanco-Piñón, A. 2009. The fossil fishes from the Sierra Madre Formation, Ocozocoautla, Chiapas, Southern Mexico. Palaeontologia Electronica, 12.2.4A:1-22. https://palaeo-electronica.org/2009_2/168/index.html

Arambourg, C. 1943. Note préliminaire sur quelques poissons fossiles nouveaux. Bulletin de la Société Géologique de France, 5:281-288.

Arambourg, C. 1954. Les poissons crétacés du Jebel Tselfat (Maroc). Éditions du Service géologique du Maroc, Rabat. 
Arratia, G. 2008. The varasichthyid and other crossognathiform fishes, and the break-up of Pangaea, p. 71-92. In Cavin, L., Longbottom, A., and Richter, M. (eds.), Fishes and the Break-up of Pangaea. Geological Society of London, Special Publication 295. Geological Society of London, London. https://doi.org/10.1144/SP295.6

Arratia, G., González-Rodríguez, K.A., and Hernández-Guerrero, C. 2018. A new pachyrhizodontid fish (Actinopterygii, Teleostei) from the Muhi quarry (Albian-Cenomanian), Hidalgo, Mexico. Fossil Record, 21:93-107. https://doi.org/10.5194/fr-21-93-2018

Arratia, G. and Tischlinger, H. 2010.The first record of Late Jurassic crossognathiform fishes from Europe and their phylogenetic importance for teleostean phylogeny. Fossil Record, 13:317-341. https://doi.org/10.1002/mmng.201000005

Bardack, D. and Teller-Marshall, S. 1980. Tselfatia, a Tethyan Cretaceous teleost: first records from North America and Yugoslavia. Journal of Paleontology, 54, 5:1075-1083.

Berg, L.S. 1937. A classification of fish-like vertebrates. Bulletin de l'Académie des Sciences de I'URSS, Classe des Sciences Mathématiques et Naturelles, 4:1277-1280.

Blainville, H.D. 1818. Nouveau Dictionnaire d'Histoire Naturelle. Poissons Fossiles. Deterville, Paris.

Blanco, A. and Cavin, L. 2003. New Teleostei from the Agua Nueva Formation (Turonian), Vallecillo (NE Mexico). Comptes Rendus Palevol, 2:299-306. https://doi.org/10.1016/S16310683(03)00064-2

Blanco, A., Stinnesbeck, W., López-Oliva, J.G., Frey, E., Adatte, T., and González, A.H. 2001. Vallecillo, Nuevo León: una nueva localidad fosilífera del Cretácico Tardío en el noreste de México. Revista Mexicana de Ciencias Geológicas, 18:186-199.

Blanco-Piñón, A. 2003. Peces Fósiles de la Formación Agua Nueva (Turoniano) en el Municipio de Vallecillo, Nuevo León, NE-México. Unpublished PhD Thesis, Universidad Autónoma de Nuevo León, Linares, Nuevo León, México.

Blanco-Piñón, A., Alvarado-Ortega, J., Rojas-León, A., and Camargo-Cruz, T. 2006. Xilitla, una asociación fosilífera del Cretácico Superior (Turoniano), San Luis Potosí, Mexico Central, p. 25. (Editot unknown), X Congreso de la Sociedad Mexicana de Paleontología. México, Ciudad de México, Noviembre 21-25, 2006. Memoria del X Congreso Nacional de Paleontología y libreto guía excursión a Tepexi de Rodríguez, Puebla. Instituto de Geología, Universidad Nacional Autónoma de México, Publicación Especial 5. Universidad Nacional Autónoma de México, Mexico City.

Blot, J. 1987. L'Ordere des Pycnodontiformes. Studi e Ricerche sui Giacimenti Terziari di Bolca, 5:1-211.

Caldwell, M.W. and Bell, G.L., Jr. 1995. Halisaurus sp. (Mosasauridae) from the Upper Cretaceous (? Santonian) of east-central Peru, and the taxonomic utility of mosasaur cervical vertebrae. Journal of Vertebrate Paleontology, 15:532-544. https://doi.org/10.1080/ 02724634.1995.10011246

Capasso, L.L., Abi Saad, P., and Taverne, L. 2009. Nursallia tethysensis sp. nov., a new pycnodont fish (Neopterygii: Halecostomi) from the Cenomanian of Lebanon. Bulletin de l'Institut Royal des Sciences Naturelles de Belgique, Sciences de la Terre, 79:117-136.

Carbot-Chanona, G. and Than-Marchese, B.A. 2013. Presencia de Enchodus (Osteichthyes: Aulopiformes: Enchodontidae) en el Maastrichtiano (Cretácico tardío) de Chiapas, México. Paleontología Mexicana, 63:8-16.

Carrillo-Bravo, J. 1971. La Plataforma de Valles-San Luis Potosí. Boletín de la Asociación Mexicana de Geólogos Petroleros, 23:1-110.

Cavin, L. 1995. Goulmimichthys arambourgi n.g, n. sp., un Pachyrhizodontidae (Actinopterygii, Teleostei) d'une nouvelle localité à nodules fossilifères du Turonien inférieur marocain. Comptes Rendus de l'Académie des sciences, Série 2, Sciences de la Terre et des Planètes, 321:1049-1054.

Cavin, L. 2001. Osteology and phylogenetic relationships of the teleost Goulmimichthys arambourgi Cavin, 1995, from the Upper Cretaccous of Goulmima, Morocco. Eclogae Geologicae Helvetiae, 94:509-536.

Cavin, L., Alexopoulos, A., and Piuz, A. 2012. Late Cretaceous (Maastrichtian) ray-finned fishes from the island of Gavdos, southern Greece, with comments on the evolutionary history of the aulopiform teleost Enchodus. Bulletin de la Société Géologique de France, 183:561-572. https://doi.org/10.2113/gssgfbull.183.6.561

Chalifa, Y. 1989. Two new species of longirostrine fishes from the early Cenomanian (late Cretaceous) of Ein-Yabrud, Israel, with comments on the phylogeny of the Dercetidae. 
Journal of Vertebrate Paleontology, 9:314-328. https://doi.org/10.1080/ 02724634.1989.10011765

Cope, E.D. 1872. On the families of fishes of the Cretaceous Formation of Kansas. Proceedings of American Philosophical Society, 12:327-357.

Cope, E.D. 1886. A contribution to the vertebrate palaeontology of Brazil. Proceedings of Proceedings of the American Philosophical Society, 23:1-21.

Cumbaa, S.L. and Murray, A.M. 2008. New Late Cretaceous pachyrhizodontid and enchodontoid fishes and associated ichthyofauna from the Northwest Territories, Canada, p. 229-256. In Arratia, G., Schultze, H.-P., and Wilson, M.V.H. (eds.), Mesozoic Fishes 4 - Homology and Phylogeny. Verlag Dr. F. Pfeil, München,.

Cuvier, G.L.C.F.G. 1817. Regne Animal, 1st Edition. Vol. 2. Chez Déterville, Paris.

Davis, J.W. 1887. The fossil fishes of the Chalk of Mount Lebanon in Syria. Scientific Transactions of the Royal Dublin Society, 3:457-636.

Díaz-Cruz, J.A., Alvarado-Ortega, J., and Carbot-Chanona, G. 2016. The Cenomanian short snout enchodontid fishes (Aulopifomes, Enchodontidae) from Sierra Madre Formation, Chiapas, southeastern Mexico. Cretaceous Research, 65:136-150. https://doi.org/10.1016/ j.cretres.2015.12.026

Dunkle, D.H. and Maldonado-Koerdell, M. 1953. Notes on some Mesozoic fossil fish remains from Mexico. Journal of the Washington Academy of Sciences, 43(10):311-317.

Fielitz, Ch. 2004. The phylogenetic relationships of the Enchodontidae (Teleostei: Aulopiformes), p. 619-634. In Arratia, G., Wilson, M.V.H., and Cloutier, R. (eds.), Recent Advances in the Origin and Early Radiation of Vertebrates. Verlag Dr. Friedrich Pfeil, München.

Fielitz, Ch. and González-Rodríguez, K.A. 2010. A new species of Enchodus (Aulopiformes: Enchodontidae) from the Cretaceous (Albian to Cenomanian) of Zimapán, Hidalgo, México. Journal of Vertebrate Paleontology, 30:1343-1351. https://doi.org/10.1080/ 02724634.2010 .501438

Forey, P.L. 1977. The Osteology of Notelops Woodward, Rhacolepis Agassiz and Pachyrhizodus Dixon (Pisces: Teleostei). Bulletin of the British Museum (Natural History), Geology, 28:125204.

Forey, P.L., Yi, L., Patterson, C., and Davies, C.E. 2003. Fossil fishes from the Cenomanian (Upper Cretaceous) of Namoura, Lebanon. Journal of Systematic Palaeontology, 1:1-227. https://doi.org/10.1017/S147720190300107X

Gervais, P. 1853. Observations relatives aux reptiles fossiles de France (première partie). Comptes Rendus de l'Académie des Sciences de Paris, 36:374-377.

Giersch, S. 2014. Die Knochenfische der Oberkreidezeit in Nordostmexiko: Beschreibung, Systematik, Vergesellschaftung, Paläobiogeographie und Paläoökologie. Doctoral dissertation, Ruprecht-Karls-Universität Heidelberg, Heidelberg, Germany.

Giersch, S., Frey, E., Stinnesbeck, W., and González González, A.H. 2008. Fossil fish assemblages of northeastern Mexico: New evidence of Mid Cretaceous actinopterygian radiation, p. 43-45. In Krempská Z. (ed.), 6th Meeting of the European Association of Vertebrate Palaeontologists, Spiŝská Nová Ves, Slovak Republic. Museum of Spiŝ, Spiŝská Nová Ves.

González-Rodríguez, K.A., Fielitz, Ch., Bravo-Cuevas, V.M., and Baños-Rodríguez, R.E. 2016. Cretaceous osteichthyan fish assemblages from Mexico. New Mexico Museum of Natural History and Science Bulletin, 71:107-119.

Goody, P.C. 1969. The relationships of certain Upper Cretaceous Teleosts with special reference to the Myctophids. Bulletin of the British Museum (Natural History), 7:1-255.

Grande, L. 1985. Recent and fossil clupeomorph fishes with materials for revision of the subgroups of clupeoids. Bulletin of the American Museum of Natural History, 181:1-372.

Gray, G.G., Pottorf, R.J., Yurewicz, D.A., Mahon, K.I., Pevear, D.R., and Chucla, R.J. 2001. Thermal and chronological record of syn- to post-Laramidae vurial and exhumation, Sierra Madre Oriental, Mexico, p. 159-181. In Bartolini, C., Buffler, R.T., and Cantú-Chapa, A. (eds.), The Western Gulf of Mexico Basin -Tectonics, Sedimentary Basins, and Petroleum Systems. American Association of Petroleum Geologists Memoir 75. American Association of Petroleum Geologists, Tulsa, Oklahoma,

Heckel, J. 1854. Über den Bau und die Eintheilung der Pycnodonten, nebst kurzer Beschreibung einiger neuen Arten derselben. Sitzungsberichte der Kaiserlichen Akademie der Wissenschaften. Mathematisch-Naturwissenschaftliche Klasse, Wein, 12:433-464. 
Heim, A. 1940. The Front Ranges of Sierra Madre Oriental, Mexico, from Ciudad Victoria to Tamazunchale. Eclogae Geologica Helvetiae, 33:315-352.

Ice, G.R. and McNulty, C.L. 1980. Foraminifers and calcispheres from Cuesta del Cura and Lower Agua Nueva (?) Formations (Cretaceous), East-Central Mexico. American Association of Petroleum Geologists Bulletin, 64:1560-1560.

Jiménez-Huidobro, P., Simões, T., and Caldwell, M.W. 2017. Mosasauroids from Gondwanan continents. Journal of Herpetology, 51:355-364. https://doi.org/10.1670/16-017

Kriwet, J. 2005. A comprehensive study of the skull and dentition of pycnodont fishes. Zitteliana, A45:135-188.

Loomis, F.B. 1900. Die anatomie und die verwandtschaft der Ganoid-und Knochen-fische aus der Kreide-Formation von Kansas, USA. Palaeontographica, 46:213-284.

López-Ramos, E. 1983. Geología de México, volumen 3, Tomo 2, 3a. Edición. D.F., México, Edición Escolar. (Publisher unknown).

Maisch, M.W. and Lehmann, J. 2000. Tselfatia formosa Arambourg, 1943 (Teleostei) from the Upper Cretaceous of Lower Saxony (Northern Germany). Neues Jahrbuch fur Geologie und Palaontologie-Monatshefte, 8:499-512.

Maldonado-Koerdell, M. 1956. Peces fósiles de México III, Nota preliminar sobre peces del Turoniano superior de Xilitla, San Luis Potosí, México. Ciencia (México), 16:31-36.

Mantell, G.A. 1822. The Fossils of the South Downs -Or, Illustrations of the Geology of Sussex. Lupton Relfe, London.

Muir, J.M. 1936. Geology of the Tampico Region. American Association of Petroleum Geologists Memoir, Tulsa, USA.

Nelson, J.S. 1994. Fishes of the World. John Wiley and Sons Inc., New York.

Nursall, J.R. 1996. The phylogeny of the pycnodont fishes, p.189-214. In Arratia, G. and Viohl, G. (eds.), Mesozoic Fishes 1 - Systematics and Paleoecology. Verlag Dr Friedrich Pfeil, München.

Oppel, M. 1811. Die Ordnungen, Familien und Gattungen der Reptilien als Prodrom einer Naturgeschichte Derselben. Joseph Lindauer, München.

Páramo-Fonseca, M.E. 2001. Los peces de la familia Pachyrhizodontidae (Teleostei) del Turoniano del Valle superior del Magdalena, Colombia, dos nuevas especies. Ingeominas, 39:51-81.

Pessagno, E.A. 1969. Upper Cretaceous stratigraphy of the western Gulf Coast area of Mexico, Texas, and Arkansas. Geological Society of America Memoir, 111:1-139. https://doi.org/ 10.1130/MEM111-p1

Pictet, F.-J. 1850. Description de Quelques Poissons Fossiles du Mont Liban. Jules-Guillaume Fick, Genève.

Poyato-Ariza, F.J. and Wenz, S. 2002. A new insight into pycnodontiform fishes. Geodiversitas, 24:139-248.

Rafinesque, C.S. 1810. Caratteri di Alcuni Nuovi Generi e Nuove Specie di Animali e Piante della Sicilia, con Varie Osservazioni Sopra i Medisimi. Per le stampe di Sanfilippo, Messina.

Rosen, D.E. 1973. Interrelationships of higher euteleostean fishes, p. 397-513. In Greenwood, P.H., Miles, R.S., and Patterson, C. (eds.), Interrelationships of Fishes. Academic Press, London.

Santiago-Carrasco, B., Martínez-Ramos, C.J., Sánchez-Bermeo, G., Chiapa-García, R., and Palacios-García, R. 2000. Informe de la carta Geológico-Minera Monterrey Gl 4-7, escala 1:250,000, estados de Coahuila, Nuevo León y Zacatecas, informe técnico. Consejo de Recursos Minerales, Pachuca, Hidalgo.

Servicio Geológico Mexicano (SGM). 2004. Carta Geológico-Minera Poza Rica F14-12, Veracruz, Puebla e Hidalgo, escala 1:50 000,1 mapa con texto. Servicio Geológico Mexicano, Pachuca, Hidalgo.

Shimada, K. 2015. Body form and paleoecology of the large Late Cretaceous bony fish, Pachyrhizodus caninus. Cretaceous Research, 52:286-291. https://doi.org/10.1016/ j.cretres.2014.10.006

Shimada, K., Schumacher, B.A., Parkin, J.A., and Palermo, J.M. 2006. Fossil marine vertebrates from the lowermost Greenhorn Limestone (Upper Cretaceous: Middle Cenomanian) in Southeastern Colorado. Memoir of the Paleontological Society, 89(suppl. to 2):1-45.

Silva, H. and Gallo, V. 2011. Taxonomic review and phylogenetic analysis of Enchodontoidei (Teleostei: Aulopiformes). Anais da Academia Brasileira de Ciências, 83:483-511. 
Sohl, N.B., Martínez, E.R., Salmerón-Ureña, P., and Soto-Jaramillo, F. 1991. Upper Cretaceous, p. 205-244. In Salvador, A. (ed.), The Geology of North America, v. J. -The Gulf of Mexico Basin. Geological Society of America, Colorado, USA.

Sorbini, L. 1976. L'Ittiofauna Cretacea di Cinto-Euganeo (Pavda-Nord Italia). Bollettino del Museo Civico di Storia Naturale di Verona, 3:469-567.

Stephenson, L.W. 1922. Some Upper Cretaceous Shells of the Rudistic group from the Tamaulipas, Mexico. Proceedings of United States Natural History Museum, 61:1-13 + 13 pls.

Taverne, L. 1983. Ostéologie et affinités systématiques de Tselfatia fromosa, teleosteen fossile du Crétacé supérieur de la Mésogée Eurafricaine. Annales de la Société Royale Zoologique de Belgique, 113:165-181.

Taverne, L. 1987. Ostéologie de Cyranichthys ornatissimus nov. gen. du Cénomanien du Zaıre et de Rhynchodercetis yovanovitchi du Cénomanien de l'Afrique du Nord. Les relations intergeneriques et la position systématique de la famille neocrétacique marine des Dercetidae (Pisces, Teleostei). Annales du Musée Royal de l'Afrique Centrale, Tervuren, Rapport Annuel, 1985-1986:93-112.

Taverne, L. 1989. Crossognathus Pictet, 1858 du Cretacé inférieur de l'Europe et systématique, paleozoogeographie et biologie des Crossognathiformes nov. ord. (Téléostéens) du Cretacé et du Tertiare. Palaeontographica Abteilung A, 207:79-105.

Taverne, L. 1991. New considerations on the osteology and phylogeny of the Cretaceous marine teleost family Dercetidae. Biologisch Jaarboek, Dodonaea, 58:94-112.

Taverne, L. 1996. Révision de Tingitanichthys heterodon (Arambourg, 1954) nov. gen. (Teleostei, Pachyrhizodontoidei) du Crétacé supérieur marin du Maroc. Biologisch Jaarboek, Dodonaea, 63:133-151.

Taverne, L. 2000a. Tselfatia formosa, téléostéen marin du Crétacé (Pisces, Actinopterygii), et la position systématique des Tselfatiiformes ou Bananogmiiformes. Geodiversitas, 22:5-22.

Taverne, L. 2000b. Ostéologie et position systématique du genre Plethodus et des nouveaux genres Dixonanogmius et Pentanogmius, poissons marins du Crétacé (Teleostei, Tselfatiiformes). Biologisch Jaarboek, Dodonaea, 67:94-123.

Taverne, L. 2006. Les poissons crétacés de Nardò. $24^{\circ}$ Caudadercetis bannikovi gen. et sp. nov. (Teleostei, Aulopiformes, Dercetidae). Considérations sur la phylogénie des Dercetida. Bollettino del Museo Civico di Storia Naturale di Veron, Geologia Paleontologia Preistoria, 30:27-48.

Taverne, L.and Gayet, M. 2004. Ostéologie et relations phylogénétiques des Protobramidae (Teleostei, Tselfatiiformes), poissons marins du Cénomanien (Crétacé Supérieur) du Liban. Cybium, 28:285-314.

Taverne, L. and Gayet, M. 2005. Phylogenetical relationships and palaeozoogeography of the marine Cretaceous Tselfatiiformes (Teleostei, Clupeocephala). Cybium, 29:65-87.

Taverne, L., Layeb, M., Layeb-Tounsi, Y., and Gaudant, J. 2015. Paranursallia spinosa n. gen., n. sp., a new Upper Cretaceous pycnodontiform fish from the Eurafrican Mesogea. Geodiversitas, 37:215-227. https://doi.org/10.5252/g2015n2a3

Taverne, L. and Liston, J. 2017. On the presence of the plethodid fish Dixonanogmius (Teleostei, Tselfatiiformes) in the marine Upper Cretaceous of Burma (Myanmar), tropical Asia. GeoEco-Trop, 41:77-84.

Vernygora, O., Murray, A.M., Luque, J., Ruge, M.L.P., and Fonseca, M.E.P. 2017. A new Cretaceous dercetid fish (Neoteleostei: Aulopiformes) from the Turonian of Colombia. Journal of Systematic Palaeontology, 16:1057-1071. https://doi.org/10.1080/ 14772019.2017.1391884

von Schlotheim, E.F. 1813. Beiträge zur Naturgeschichte der Versteinerungen in geognostischer Hinsicht. Leonhard's Taschenbuch für die gesammte Mineralogie mit Hinsicht auf die neuesten. Entdeckungen, 7:3-134.

Woodward, A.S. 1901. Catalogue of Fossil Fishes in the British Museum (Natural History), Part 4. British Museum (Natural History), London. https://doi.org/10.5962/bhl.title.61854 